\title{
An Acylation-Finkelstein Approach to Radioiodination of Bioactives: The Role of Amide Group Anchimeric Assistance
}

\author{
Richard Fjellaksel, ${ }^{\mathrm{a}, \mathrm{b}, \mathrm{c}}$ Damir Dugalic, ${ }^{\mathrm{b}, \mathrm{c}}$ Taye B. Demissie, ${ }^{\mathrm{c}, \mathrm{d}}$ \\ Patrick Riss, ${ }^{\text {e.f.g }}$ Ole-Kristian Hjelstuen, ${ }^{\mathrm{b}}$ Rune Sundset, ${ }^{\text {a,h }}$ and Jørn H. Hansen ${ }^{\mathrm{c}^{*}}$ \\ ${ }^{a}$ Medical Imaging Group, Department of Clinical Medicine, UiT The Arctic University of \\ Norway, 9037 Troms $\phi$, Norway. \\ ${ }^{b}$ Drug Transport and Delivery Group, Department of Pharmacy, UiT The Arctic University of \\ Norway, 9037 Troms $\phi$, Norway. \\ ${ }^{c}$ Organic Chemistry Group, Department of Chemistry, UiT The Arctic University of Norway, \\ 9037 Troms $\phi$, Norway. \\ ${ }^{d}$ Hylleraas Centre for Quantum Molecular Sciences, Department of Chemistry, UiT The Arctic \\ University of Norway, 9037 Troms $\phi$, Norway. \\ ${ }^{e}$ Department of neuropsychiatry and psychosomatic medicine, Oslo University Hospital, Oslo, \\ Norway. \\ ${ }^{f}$ Realomics SFI, Department of Chemistry, University of Oslo, PO BOX 1033, Oslo 0371, \\ Norway. \\ ${ }^{g}$ Norsk Medisinsk Syklotronsenter AS, Postboks 4950 Nydalen, 0424 Oslo \\ ${ }^{h}$ PET imaging center, Division of diagnostics, University Hospital of North Norway, 9038 \\ Troms $\phi$, Norway.
}

\section{KEYWORDS}

Finkelstein. Amide anchimeric assistance. Radioiodination. DFT mechanism. Bioactives.

\begin{abstract}
Herein, we report a straight-forward sequential acylation-Finkelstein approach to achieve iodination of amine containing bioactives. The utility was demonstrated by successful radiolabelling with ${ }^{123} \mathrm{I}$ in high radiochemical yield. Moreover, microwave-assisted Finkelstein reaction can be employed to enhance conversion and reaction rates to obtain the desired iodides. The method is of interest for radioiodination of amine-containing bioactives. The mechanistic details of the iodination process were studied by kinetics and density functional theory (DFT) calculations, which revealed the mechanistic complexity of the reaction involving amide group anchimeric assistance. We disclose a number of fundamental aspects of amide group anchimeric assistance in substitution reactions.
\end{abstract}




\section{INTRODUCTION}

Continued advances in medical imaging require effective and versatile radiolabeling methods. Imaging techniques, such as Single Photon Emission Computed Tomography (SPECT) and Positron Emission Tomography (PET), increasingly employ radiolabeled bioactive organic molecules as radiotracers. Important criteria for production of clinical radiotracers are; rapid radiolabeling reaction rates, high radiochemical yield (RCY) and high specific activity. ${ }^{[1]}$ Herein, we disclose a straight-forward radioiodination protocol for bioactives based on a sequential acylation-Finkelstein approach. However, the mechanistic complexity of the substitution process requires careful consideration before this strategy can be applied, and, as such, we have conducted in-depth mechanistic analyses to reveal the detailed nature of the processes involved.

The intramolecular nucleophilic participation of functional groups adjacent to reactive centers, commonly known as anchimeric assistance, has been widely studied by the physical organic chemistry community over the past 60 years or so. ${ }^{[2-8]}$ However, anchimeric assistance by amide groups has only been sparsely reported ${ }^{[9]}$ despite recent studies indicating its importance in biological systems, such as catalytic enzyme glycoside bond breakage in O-GlcNAcases and Bhexosaminidases. ${ }^{[10-14]}$ A study by Garavelli and co-workers ${ }^{[15]}$ reported experimental and computational evidence for amide group anchimeric assistance in acid-catalyzed ether cleavage reactions. A thorough general understanding of the thermodynamic and kinetic details of anchimeric assistance provided by amide groups is lacking, and would be a valuable addition to the reaction design toolkit and to the enhanced understanding of the role of amide groups in biological systems.

The use of anchimeric assistance by adjacent amino groups as a strategy to enhance introduction of radioactive fluoride was recently described by Médoc and co-workers, in which radiosubstitution via activated aziridinium intermediates was shown to successfully lead to ${ }^{18} \mathrm{~F}$ labelling (Scheme 1A). ${ }^{[16]}$ Inspired by the previous works, and the need to enhance fundamental understanding of amide group anchimeric assistance, we decided to explore a straight-forward acylation-Finkelstein strategy (Scheme 1B) for iodide incorporation. Despite the weak bond strength of the $\mathrm{C}$-I bond relative to the $\mathrm{C}-\mathrm{Cl}$ bond, the Finkelstein reaction is driven forward by the 
precipitation of sodium chloride in the solvent (typically acetone), thereby rendering the chloride displacement irreversible. ${ }^{[17-18]}$ At certain chain lengths $(n=2-7)$, one might expect the adjacent amide group to engage in anchimeric assistance in the displacement of the chloride ion - in competition with direct bimolecular substitution. The effects of this mechanistic complication are a major topic of this paper.

(A) Anchimerically assisted radiofluorination by Médoc et al.

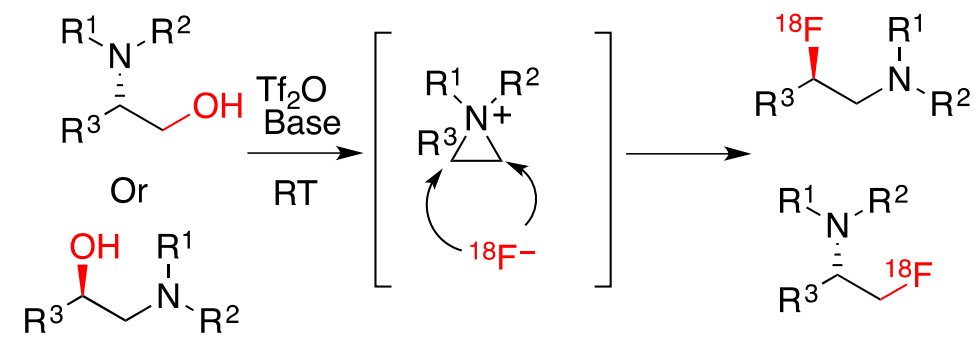

(B) Acylation-Finkelstein approach to radioiodination

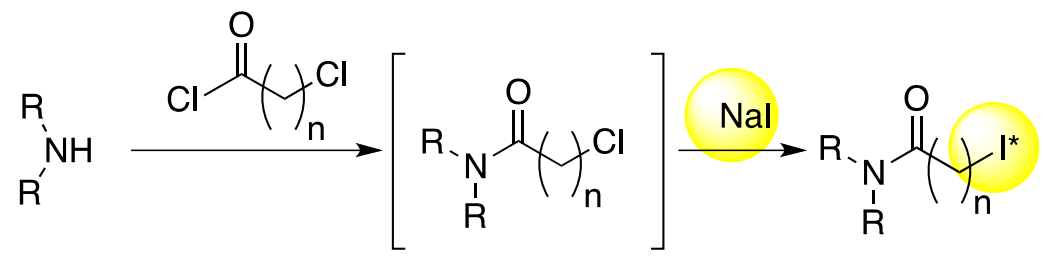

Scheme 1: Use of anchimerically assisted radiofluorination by Médoc et al. ${ }^{[16]}$ (A) versus acylation/Finkelstein approach (B, current work).

In this paper we aim to; (1) disclose our studies of the acylation-Finkelstein approach to iodination and radioiodination of a bioactive model molecules, and; (2) unravel the mechanistic complexity involved in the substitution processes - in particular the influence of amide group anchimeric assistance. We have explicitly studied the latter using combined experimental and computational techniques. We have compared relative rates of substitution depending on carbon chain lengths and the ring size of the activated intermediate electrophile. Since amide groups have not been extensively studied for their ability to effect anchimeric assistance, we have conducted a detailed computational study of the mechanistic details of such processes using density functional theory (DFT) calculations. These studies are necessary to guide future applications of this iodination strategy to other bioactives, and they provide a fundamental insight into the details of 
amide group anchimeric assistance. To validate our approach for radioiodination, we have demonstrated that an acylated analogue of a bioactive molecule can be effectively radiolabelled.

\section{EXPERIMENTAL DETAILS}

\section{General experimental details}

All solvents and reagents were obtained from Sigma Aldrich (Sigma-Aldrich Norway AS) except $\mathrm{Na}^{123}$ I. $\mathrm{Na}^{123} \mathrm{I}$ was obtained from GE Healthcare. Instruments used: Microwave Anton Parr Monowave $300^{\circledR}$, Biotage SP1 Flash Chromatography systems ${ }^{\circledR}$, HRMS: Thermo scientific LTQ Orbitrap XL + Electrospray ion source (ION-MAX) - The instrument was made at Thermo's factory in Bremen, Germany, IR: Varian 7000e FT-IR spectrometer, Pike miracle ATR. NMR: 400 MHz Brüker Avance III HD equipped with a 5 mm SmartProbe BB/1h (BB = 19F, 31p-15N), HPLC systems: Waters 2545 HPLC pump. Waters 2998 PDA detector, 200-500nm. Waters 2767 sample manager. XBridge ${ }^{\circledR}$ prep C18 $5 \mu \mathrm{m} \mathrm{OBD}^{\mathrm{tm}} 19 \times 250 \mathrm{~mm}$ column. UPLC systems: Acquity UPLC H class. Acquity column manager. Acquity PDA detector. Acquity UPLC ${ }^{\circledR}$ BEH C18 $1.7 \mu \mathrm{m}$. 2,1x50nm column, Determination of purity by UPLC: Column at $50^{\circ} \mathrm{C}$, the same method used for all analyses. Method: $0,6 \mathrm{~mL} / \mathrm{min}$. initial $\% \quad \mathrm{H}_{2} \mathrm{O} \quad 0.1 \%$ TFA (Trifluoroacetic acid), $5 \%$ ACN(Acetonitrile) $0.1 \%$ TFA. Then linear change during 10 minutes to $50 \% \mathrm{H}_{2} \mathrm{O} 0.1 \%$ TFA, 50\% Acetonitrile $0.1 \%$ TFA. Semi-preperative HPLC for radiochemistry: DIONEX HPLC system, HPLC pump P680, automated sample injector ASI-100, PDA-detector PDA-100 with XBridge ${ }^{\circledR}$

prep C18 5 $\mu \mathrm{m}$ OBD $^{\mathrm{tm}} 19 \times 250 \mathrm{~mm}$ column, analytical XBridge ${ }^{\circledR} \mathrm{C} 183 \mu \mathrm{m} 2.1 \times 150 \mathrm{~mm}$ column and "Radioactivity flow detector for HPLC LB 509" (BERTHOLD TECHNOLOGIES). All experiments were repeated at least twice.

\section{Chemical synthesis protocols and characterization}

2-(4-tert-Butylphenyl)-4-(piperazin-1-yl)-1H-benzo [d]imidazole (1)

Compound 1 was obtained as previously described, ${ }^{[19]}$ as a white powder (489 mg, 96\% yield). Purity 97.2\% ${ }^{1} \mathrm{H}-\mathrm{NMR}$ (400MHz DMSO-d6), $\delta$ in ppm=9.67 (Br s, 1H), 8.49 (d, 8.0 Hz, 2H), 7.71(d, 8.0 Hz, 2H), 7.53(d, 8.0 Hz, 1H), 7.48 (t, 1H), 7.13 (d, 8.0 Hz, 1H), 3.45-3.37(m, 8H), 1.34 (s, 9H). ${ }^{13}$ C-NMR (101 MHz DMSO-d6), $\delta$ in ppm = 156.5, 148.9, 139.5, 132.9, 129.2, 126.7, 
126.1, 125.4, 120.2, 114.0, 108.4, 47.8, 42.7, 35.1, 30.8. HRMS (ESI) $[\mathrm{M}+\mathrm{H}]^{+}$for $\mathrm{C}_{21} \mathrm{H}_{27} \mathrm{~N}_{4} \mathrm{~m} / \mathrm{z}$ Found 335.2236, Calculated: 335.2236. IR (Neat) 2955, 2689, 2466, 1622, 1459, 1383.

\section{1-(4-(2-(4-tert-butylphenyl)-1H-benzo[d]imidazol-4-yl) piperazin-1-yl)-2-chloroethanone (2a)}

$0.2 \mathrm{~g}(0.6 \mathrm{mmol})$ of 2-(4-tert-Butylphenyl)-4-(piperazin-1-yl)-1H-benzo[d]imidazole (1) was added to a solution containing $12 \mathrm{ml}$ DMF (anhydrous) and $0.31 \mathrm{ml}$ (1.86 mmol, 3 equiv.) diisopropyl ethylamine (DIPEA). The solution was cooled down to $0^{\circ} \mathrm{C}$ in an ice bath under inert conditions and $0.15 \mathrm{ml}\left(1.86 \mathrm{mmol}, 3\right.$ equiv.) chloroacetyl chloride was added at $0^{\circ} \mathrm{C}$. The solution was stirred for 1 hour and then warmed to $27^{\circ} \mathrm{C}$. The reaction was monitored by TLC. DMF was then evaporated on a rotavap. The reaction mixture was chromatographed on biotage SP1 flash chromatography systems by a Biotage snap ultra C18rp $12 \mathrm{~g}$ column. $15 \mathrm{ml} / \mathrm{min}$. At 20 minutes linear change to $100 \% \mathrm{ACN}$. Fractions were collected and the solvents were removed by evaporation to provide a white powder (166 mg, $67 \%$ yield). Purity $97.21 \%{ }^{1} \mathbf{H}$ NMR (400 MHz, Methanol- $\left.d_{4}\right) \delta 8.02(\mathrm{~d}, J=8.4 \mathrm{~Hz}, 2 \mathrm{H}), 7.57(\mathrm{~d}, J=8.4 \mathrm{~Hz}, 2 \mathrm{H}), 7.22(\mathrm{~d}, J=7.9 \mathrm{~Hz}, 1 \mathrm{H}), 7.16(\mathrm{t}$, $J=7.8 \mathrm{~Hz}, 1 \mathrm{H}), 6.74(\mathrm{~d}, J=7.5 \mathrm{~Hz}, 1 \mathrm{H}), 4.31(\mathrm{~s}, 2 \mathrm{H}), 3.85(\mathrm{dt}, J=16.1,5.2 \mathrm{~Hz}, 2 \mathrm{H}), 3.40(\mathrm{t}, J=$ $5.0 \mathrm{~Hz}, 2 \mathrm{H}), 3.37-3.32(\mathrm{~m}, 2 \mathrm{H}), 1.36$ (s, 9H). ${ }^{13} \mathbf{C}$ NMR (101 MHz, Methanol- $\left.d_{4}\right) \delta$ 167.7, 155.0, 152.0, 142.9, 138.8, 134.8, 127.9, 127.8, 127.0, 125.0, 110.8, 108.3, 52.1, 51.6, 47.4, 43.4, 42.0, 35.8, 31.6. HRMS (ESI) $[\mathrm{M}+\mathrm{H}]^{+}$for $\mathrm{C}_{23} \mathrm{H}_{28} \mathrm{ON} \mathrm{N}_{4} \mathrm{Cl} \mathrm{m} / \mathrm{z}$ Found 411.1955. Calculated 411.1946 IR (Neat) 2961, 1644, 1437, 1234, 1015, 842, 788, 738.

\section{1-(4-(2-(4-tert-butylphenyl)-1H-benzo[d]imidazol-4-yl)piperazin-1-yl)-2-iodoethanone (4a)}

$58 \mathrm{mg}(0.15 \mathrm{mmol})$ of compound 2a was added to a solution of $5 \mathrm{ml}$ acetone and $500 \mathrm{mg}(3.3$ mmol, 25 equiv.) NaI. The reaction was stirred for 1 hour. The reaction mixture was filtered and then chromatographed on Biotage SP1 flash chromatography systems using a Biotage snap ultra C18rp 12g column. $15 \mathrm{ml} / \mathrm{min}$. At 20 minutes linear change to $100 \%$ ACN. Fractions were collected and the solvents were removed by evaporation to provide a white powder ( $23 \mathrm{mg}, 32 \%$ yield). Purity 95.38\%. ${ }^{1}$ H NMR (400 MHz, Acetone- $\left.d_{6}\right) \delta 8.15(\mathrm{~d}, J=8.3 \mathrm{~Hz}, 2 \mathrm{H}), 7.57(\mathrm{~d}, J=8.3 \mathrm{~Hz}$, 2H), $7.19-7.00(\mathrm{~m}, 2 \mathrm{H}), 6.63(\mathrm{~d}, J=7.1 \mathrm{~Hz}, 1 \mathrm{H}), 3.97$ (s, 2H), 3.78 (s, 4H), 3.72 (s, 2H), 3.54 (s, 2H), 1.36 (s, 9H). ${ }^{13} \mathrm{C}$ NMR (101 MHz, Acetone- $\left.d_{6}\right) \delta 166.9,153.6,149.9,143.2,138.1,136.0$, 128.6, 127.2, 126.6, 124.2, 108.3, 105.9, 50.5, 50.2, 47.9, 42.7, 35.4, 31.5, 2.3 HRMS (ESI) 
$[\mathrm{M}+\mathrm{H}]^{+}$for $\mathrm{C}_{23} \mathrm{H}_{28} \mathrm{ON} 4 \mathrm{I}$ m/z Found 503.1300. Calculated 503.1308 IR (Neat) 2961, 1637, 1437, $1015,841,788,737$.

1-(4-(2-(4-tert-butylphenyl)-1H-benzo[d]imidazol-4 yl)piperazin-1-yl)-3-chloropropan-1-one (2b)

$0.2 \mathrm{~g}$ (0.54 mmol) 1 was added to a solution containing $5 \mathrm{ml} \mathrm{DMF} \mathrm{(anhydrous)} \mathrm{and} 0.26 \mathrm{~mL}$ (1.62 mmol, 3 equiv.) DIPEA. The solution was cooled to $0^{\circ} \mathrm{C}$ with an ice bath under inert conditions and $0.14 \mathrm{~mL}$ (1.62 mmol, 3 equiv.) chloropropinoyl chloride $\mathbf{3 b}$ was added at $0^{\circ} \mathrm{C}$. The solution was warmed to room temperature and stirred for 18 hours. The solvents were evaporated by a rotavapor. The reaction mixture was then diluted with DCM and chromatographed on Biotage SP1 flash chromatography systems using a Biotage snap ultra C18rp $12 \mathrm{~g}$ column. $15 \mathrm{~mL} / \mathrm{min}$. At 20 minutes linear change to $100 \%$ ACN. The solvents were removed by evaporation to provide a white powder (99 mg, 46.7\% yield). Purity $97.97 \%{ }^{1} \mathbf{H}$ NMR (400 MHz, Acetone- $\left.d_{6}\right) \delta 8.15$ (t, $J$ = 9.0, 7.3 Hz, 2H), $7.55(\mathrm{~d}, J=7.1 \mathrm{~Hz}, 2 \mathrm{H}), 7.17-7.03(\mathrm{~m}, 2 \mathrm{H}), 6.60(\mathrm{~d}, J=6.5 \mathrm{~Hz}, 1 \mathrm{H}), 3.85(\mathrm{t}$, $J=7.7,7.3 \mathrm{~Hz}, 2 \mathrm{H}), 3.78(\mathrm{dd}, J=35.9,8.7 \mathrm{~Hz}, 4 \mathrm{H}), 3.64(\mathrm{~s}, 2 \mathrm{H}), 3.53(\mathrm{~d}, J=4.7 \mathrm{~Hz}, 2 \mathrm{H}), 2.93(\mathrm{~d}$, $J=6.7 \mathrm{~Hz}, 2 \mathrm{H}), 1.35(\mathrm{~s}, 9 \mathrm{H}) .{ }^{13} \mathrm{C}$ NMR $\left(101 \mathrm{MHz}\right.$, Acetone- $\left.d_{6}\right) \delta 168.55,153.51,149.87,143.29$, 138.08, 136.03, 128.65, 127.17, 126.53, 124.20, 108.26, 105.86, 50.94, 50.41, 46.07, 42.28, 41.06, 36.50, 35.33, 31.48 HRMS (ESI) $[\mathrm{M}+\mathrm{H}]^{+}$for $\mathrm{C}_{24} \mathrm{H}_{30} \mathrm{ON} \mathrm{ON}_{4} \mathrm{Cl} / \mathrm{z}$ Found 425.2099. Calculated 425.2108 IR (Neat) 2964, 1629, 1465, 1438, 1197, 1130, 1014.

\section{1-(4-(2-(4-tert-butylphenyl)-1H-benzo[d]imidazol-4-yl)piperazin-1-yl)-3-iodopropan-1-one (4b)}

$0.047 \mathrm{~g}(0.11 \mathrm{mmol})$ of 1-(4-(2-(4-tert-butylphenyl)-1H-benzo[d]imidazol-4-yl)piperazin-1-yl)3-chloropropan-1-one (compound 4a) was added to a solution containing $3 \mathrm{~mL}$ acetone and $0.1 \mathrm{~g}$ (0.66 mmol, 5.0 equiv.) NaI. The solution was heated to $55^{\circ} \mathrm{C}$ under reflux and stirred for 16 hours. Then the solution was filtered and transferred to a vial for HPLC. Method for HPLC separation: 25 $\mathrm{mL} / \mathrm{min}$. Initial $95 \% \mathrm{H}_{2} \mathrm{O}, 5 \% \mathrm{ACN}$ and $0.1 \%$ TFA. At 15 minutes linear change to $5 \% \mathrm{H}_{2} \mathrm{O}, 95 \%$ ACN $0.1 \%$ TFA. The product fractions were collected and lyophilized to give a white powder (23 mg, 37\% yield). Purity 95.38\%. ${ }^{1}$ H NMR (400 MHz, Acetone- $\left.d_{6}\right) \delta 8.22(\mathrm{~d}, J=8.7 \mathrm{~Hz}, 2 \mathrm{H}), 7.66$ $(\mathrm{d}, J=8.7 \mathrm{~Hz}, 2 \mathrm{H}), 7.45(\mathrm{~d}, J=8.1 \mathrm{~Hz}, 1 \mathrm{H}), 7.38-7.30(\mathrm{~m}, 1 \mathrm{H}), 6.98(\mathrm{~d}, J=7.8 \mathrm{~Hz}, 1 \mathrm{H}), 3.81(\mathrm{~s}$, 4H), $3.50-3.34(\mathrm{~m}, 4 \mathrm{H}), 3.29(\mathrm{~s}, 2 \mathrm{H}), 3.09$ (t, $J=7.3 \mathrm{~Hz}, 2 \mathrm{H}), 1.37(\mathrm{~s}, 9 \mathrm{H}) .{ }^{13} \mathrm{C}$ NMR $(101 \mathrm{MHz}$ 
Acetone- $\left.d_{6}\right) \delta 169.5,156.6,150.1,141.7,141.6,135.5,129.6,128.7,127.1,126.7,126.6,123.5$, 113.2, 108.6, 52.1, 51.6, 45.8, 42.2, 37.7, 35.7, 31.3, -0.5. HRMS (ESI) $[\mathrm{M}+\mathrm{H}]^{+}$for $\mathrm{C}_{24} \mathrm{H}_{30} \mathrm{ON}_{4} \mathrm{I}$ m/z Found 517.1462. Calculated 517.1459. IR (Neat) 3232, 2961, 1710, 1616, 1476, 1360, 1235, 1022.

\section{1-(4-(2-(4-tert-butylphenyl)-1H-benzo[d]imidazol-4-yl)piperazin-1-yl)-4-chlorobutan-1-one (2c)}

0.2 g (0.54 mmol) 2-(4-tert-Butylphenyl)-4-(piperazin-1-yl)-1H-benzo[d]imidazole (1) was added to a solution containing $5 \mathrm{ml}$ DMF (anhydrous) and $0.28 \mathrm{ml}$ (1.62 mmol 3 equiv.) DIPEA. The solution was cooled down to $0^{\circ} \mathrm{C}$ in an ice bath under inert conditions and $0.9 \mathrm{~mL}(1.6 \mathrm{mmol}$, 3 equiv.) chlorobutanoyl chloride $3 \mathbf{c}$ was added at $0^{\circ} \mathrm{C}$. The solution was warmed to room temperature and stirred for 2 hours. The reaction was monitored by TLC. The reaction mixture was transferred to a separatory funnel. First $0.2 \mathrm{~mL} 1 \mathrm{M} \mathrm{HCl}$ was added then $40 \mathrm{~mL}$ of water followed by $1 \mathrm{M} \mathrm{NaOH}$ to give a pH 7-8. The solution was washed with $3 \times 40 \mathrm{~mL}$ DCM. The organic phase was dried over sodium sulfate and filtered. Then the residue was dissolved in DCM and chromatographed on biotage SP1 flash chromatography systems using a Biotage snap ultra C18rp $12 \mathrm{~g}$ column. Flow rate: $15 \mathrm{ml} / \mathrm{min}$. 20 minutes linear change to $100 \% \mathrm{ACN}$. Fractions were collected and the solvents were removed by evaporation to provide a white powder (105 mg, 44\% yield). Purity 95.83\%. ${ }^{1} \mathbf{H}$ NMR (400 MHz, Acetone- $\left.d_{6}\right) \delta 11.87$ (s, $\left.1 \mathrm{H}\right), 8.14$ (ddt, $J=25.2,12.5$, $8.2,6.4 \mathrm{~Hz}, 2 \mathrm{H}), 7.66-7.37(\mathrm{~m}, 3 \mathrm{H}), 7.25-6.86(\mathrm{~m}, 2 \mathrm{H}), 6.58(\mathrm{dd}, J=6.8,2.0 \mathrm{~Hz}, 1 \mathrm{H}), 3.80(\mathrm{q}$, $J=4.6 \mathrm{~Hz}, 4 \mathrm{H}), 3.71(\mathrm{t}, J=6.5 \mathrm{~Hz}, 4 \mathrm{H}), 3.59(\mathrm{~d}, J=5.6 \mathrm{~Hz}, 2 \mathrm{H}), 2.61(\mathrm{t}, J=7.0 \mathrm{~Hz}, 2 \mathrm{H}), 2.11(\mathrm{q}$, $J=6.8 \mathrm{~Hz}, 2 \mathrm{H}), 1.37$ (s, 9H). ${ }^{13} \mathbf{C}$ NMR $\left(101 \mathrm{MHz}\right.$, Acetone- $\left.d_{6}\right) \delta$ 170.4, 153.5, 149.5, 143.9, 137.3, 137.0, 128.9, 127.0, 126.6, 124.3, 107.6, 104.7, 50.8, 50.3, 46.1, 45.6, 42.2, 35.4, 31.5. HRMS (ESI) $[\mathrm{M}+\mathrm{H}]^{+}$for $\mathrm{C}_{25} \mathrm{H}_{32} \mathrm{ON}_{4} \mathrm{Cl} \mathrm{m} / \mathrm{z}$ Found 439.2257. Calculated 439.2259. IR (Neat) 2962, 1592, $1463,1269,1017,842$.

\section{2-(4-tert-butylphenyl)-6-iodo-4-(piperazin-1-yl)-1H-benzo[d]imidazole (5)}

0.36 g 1-(4-(2-(4-tert-butylphenyl)-1H-benzo[d]imidazol-4-yl)piperazin-1-yl)-4-chlorobutan-1one ( $0.81 \mathrm{mmol}, 1$ equiv.) was added to a solution containing $1.22 \mathrm{~g} \mathrm{NaI}(8.1 \mathrm{mmol}, 10$ equiv.) and $10 \mathrm{~mL}$ of acetone. The solution was heated to $55^{\circ} \mathrm{C}$ under reflux and stirred for 16 hours. Then the solution was filtered and transferred to a vial for HPLC. Method for HPLC separation; flow rate $25 \mathrm{ml} / \mathrm{min}$. Initial 95\% $\mathrm{H}_{2} \mathrm{O} 0.1 \%$ TFA, 5\% ACN. 15 minutes linear change to 5\% $\mathrm{H}_{2} \mathrm{O}, 95 \% \mathrm{ACN}$ 
$0.1 \%$ TFA. The product fractions were collected and lyophilized to give white powder $(73.5 \mathrm{mg}$, 20\%). Purity 95.21\%. ${ }^{1} \mathbf{H}_{\left.\text {NMR (400 MHz, DMSO- } d_{6}\right)} \delta 9.32(\mathrm{~s}, 1 \mathrm{H}), 8.22(\mathrm{~d}, J=8.4,1.8 \mathrm{~Hz}, 1 \mathrm{H})$, 7.57 (d, 1H), 7.49 (d, $J=8.2 \mathrm{~Hz}, 1 \mathrm{H}), 6.56$ (d, $J=7.8 \mathrm{~Hz}, 1 \mathrm{H}), 3.35$ (s, 8H), 1.34 (d, $J=1.7 \mathrm{~Hz}$, 9H). ${ }^{13}$ C NMR (101 MHz, DMSO- $\left.d_{6}\right) \delta 152.8,131.8,127.3,126.8,125.4,99.5,68.3,60.2,46.6$, 42.7, 34.6, 31.0, 27.4, 21.8.HRMS (ESI) $[\mathrm{M}+\mathrm{H}]^{+}$for $\mathrm{C}_{21} \mathrm{H}_{26} \mathrm{~N}_{4} \mathrm{I} \mathrm{m} / \mathrm{z}$ Found 461.1205. Calculated 461.1197 IR (Neat): 2963, 2839, 1619, 1489, 1273, 1023.

1-(4-(2-(4-tert-butylphenyl)-1H-benzo[d] imidazol-4-yl) piperazin-1-yl)-5-chloropentan-1-one (2d)

$0.15 \mathrm{~g}$ (0.405 mmol) 2-(4-tert-Butylphenyl)-4-(piperazin-1-yl)-1H-benzo[d]imidazole (1) was added to a solution containing $5 \mathrm{ml}$ DMF (anhydrous) and $0.21 \mathrm{~mL}$ (1.2 mmol, 3 equiv.) DIPEA. The solution was cooled down to $0^{\circ} \mathrm{C}$ in ice bath, under inert conditions and $0.16 \mathrm{~mL}(1.2 \mathrm{mmol}, 3$ equiv.) chlorovaleroryl chloride $3 \mathbf{d}$ was added at $0^{\circ} \mathrm{C}$. The solution was then warmed to room temperature and stirred for 18 hours. The solvent was evaporated on a rotavapor. The residue was then dissolved in DCM and chromatographed on Biotage SP1 flash chromatography systems by a Biotage snap ultra C18rp 12g column. Flow rate: $15 \mathrm{ml} / \mathrm{min}$. 20 minutes linear change to 100\% ACN. ${ }^{1} \mathrm{H}$ NMR was obtained, but the compound showed impurities. The compound was then further purified on HPLC. Method for HPLC separation, $25 \mathrm{~mL} / \mathrm{min}$. Initial 95\% $\mathrm{H}_{2} \mathrm{O} 0.1 \% \mathrm{TFA}$, $5 \%$ ACN $0.1 \%$ TFA. At 15 minutes linear change to 5\% $\mathrm{H}_{2} \mathrm{O} 0.1 \%$ TFA, 95\% ACN 0.1\% TFA. Fractions were collected and solvents were removed by evaporation to provide a white powder. (44 mg, 24\% yield). Purity 99.46\%. ${ }^{1}$ H NMR (400 MHz, Acetone- $\left.d_{6}\right) \delta 11.92$ (s, 1H), $8.34-8.01$ (m, 2H), $7.68-7.46(\mathrm{~m}, 2 \mathrm{H}), 7.17-7.03(\mathrm{~m}, 2 \mathrm{H}), 6.58(\mathrm{~s}, 1 \mathrm{H}), 3.78(\mathrm{~d}, J=14.9 \mathrm{~Hz}, 4 \mathrm{H}), 3.68-3,55$ $(\mathrm{m}, 6 \mathrm{H}), 2.47(\mathrm{t}, 2 \mathrm{H}), 1.90-1.80(\mathrm{~m}, 2 \mathrm{H}), 1.80-1.70(\mathrm{~m}, 2 \mathrm{H}), 1.36(\mathrm{~s}, 9 \mathrm{H}) .{ }^{13} \mathrm{C}$ NMR (101 MHz, Acetone- $\left.d_{6}\right) \delta 171.2,153.4,149.6,143.9,137.3,137.0,128.8,127.1,126.5,126.5,124.2,107.6$, 104.7, 50.9, 50.3, 46.2, 45.6, 45.6, 42.2, 35.3, 33.1, 32.6, 31.5, 23.3. HRMS (ESI) $[\mathrm{M}+\mathrm{H}]^{+}$for $\mathrm{C}_{26} \mathrm{H}_{34} \mathrm{ON}_{4} \mathrm{Cl} \mathrm{m} / \mathrm{z}$ Found 453.2413. Calculated 453.2416. IR (neat) 2966, 1631, 1465, 1438, 1198, 1131,1015 .

1-(4-(2-(4-tert-butylphenyl)-1H-benzo[d] imidazol-4-yl) piperazin-1-yl)-5-iodopentan-1-one (4d)

$0.02 \mathrm{~g}$ (0.044 mmol) 1-(4-(2-(4-tert-butylphenyl)-1H-benzo[d]imidazol-4-yl)piperazin-1-yl)-5chloropentan-1 one (2d) was added to a solution containing $2 \mathrm{ml}$ of acetone and $66 \mathrm{mg}(0.44$ mmol, 10 equiv.) NaI. The solution was heated to $160^{\circ} \mathrm{C}$ in the microwave for 5 minutes. The 
reaction mixture was filtered and separated by HPLC. HPLC method used for separation; 25ml/min. initial $95 \% \mathrm{H}_{2} \mathrm{O} 0.1 \%$ TFA, 5\% ACN 0.1\% TFA. At 15 minutes linear change to $5 \% \mathrm{H}_{2} \mathrm{O} 0.1 \%$ TFA, 95\% ACN 0.1\% TFA. After HPLC purification, the compound was lyophilized to provide a white powder (6.2 mg, 26\% yield). Purity 99.14\%. ${ }^{1}$ H NMR (400 MHz, Acetone- $\left.d_{6}\right) \delta 8.25(\mathrm{~d}, J=$ $8.5 \mathrm{~Hz}, 2 \mathrm{H}), 7.67(\mathrm{~d}, J=8.4 \mathrm{~Hz}, 2 \mathrm{H}), 7.49(\mathrm{~d}, J=8.1 \mathrm{~Hz}, 1 \mathrm{H}), 7.36(\mathrm{t}, J=8.0 \mathrm{~Hz}, 1 \mathrm{H}), 7.01(\mathrm{~d}, J=$ $7.8 \mathrm{~Hz}, 1 \mathrm{H}), 3.84-3.67(\mathrm{~m}, 4 \mathrm{H}), 3.38-3.21(\mathrm{~m}, 6 \mathrm{H}), 2.48(\mathrm{t}, J=7.3 \mathrm{~Hz}, 2 \mathrm{H}), 1.96-1.82(\mathrm{~m}, 2 \mathrm{H})$, $1.77-1.67$ (m, 2H), 1.37 (s, 9H). ${ }^{13}$ C NMR (101 MHz, Acetone- $\left.d_{6}\right) \delta$ 171.2, 156.7, 150.1, 141.6, 135.3, 129.3, 128.9, 127.1, 126.8, 123.3, 113.5, 108.7, 52.2, 51.8, 48.3, 46.0, 44.5, 42.0, 35.7, 34.0, 32.2, 31.3, 26.8, 7.5. HRMS (ESI) $[\mathrm{M}+\mathrm{H}]^{+}$for $\mathrm{C}_{26} \mathrm{H}_{34} \mathrm{ON}_{4} \mathrm{I} \mathrm{m} / \mathrm{z}$ Found 545.1765. Calculated 545.1772. IR (neat) 2961, 2923, 1712, 1609, 1361, 1258, 1235, 1012.

1-(4-(2-(4-tert-butylphenyl)-1H-benzo[d]imidazol-4-yl) piperazin-1-yl)-6-chlorohexan-1-one (2e)

$0.089 \mathrm{~g}$ (0.23 mmol) 2-(4-tert-Butylphenyl)-4-(piperazin-1-yl)-1H-benzo[d]imidazole (1) was added to a solution containing $5 \mathrm{ml}$ DMF (anhydrous) and $0.01 \mathrm{ml}$ (0.69 mmol, 3 equiv.) DIPEA. The solution was cooled down to $0^{\circ} \mathrm{C}$ in an ice bath under inert conditions and $0.08 \mathrm{ml}(0.69 \mathrm{mmol}$, 3 equiv.) chlorohexanoyl chloride $\mathbf{3 e}$ was added at $0^{\circ} \mathrm{C}$. The solution was warmed to room temperature and stirred for 18 hours. The solvent was evaporated on a rotavapor. The residue was then dissolved in DCM and chromatographed on Biotage SP1 flash chromatography systems by a Biotage snap ultra C18rp 12g column. Flow rate: $15 \mathrm{ml} / \mathrm{min}$. At 20 minutes linear change to $100 \%$ ACN. The solvents were removed by evaporation to provide a white powder (104 mg, 65\% yield).

Purity 99.17\%. ${ }^{1} \mathbf{H}$ NMR (400 MHz, Acetone- $\left.d_{6}\right) \delta 11.91(\mathrm{~s}, 1 \mathrm{H}), 8.16(\mathrm{dd}, J=8.3,3.0 \mathrm{~Hz}, 2 \mathrm{H})$, $7.58(\mathrm{dd}, J=8.4,2.8 \mathrm{~Hz}, 2 \mathrm{H}), 7.10(\mathrm{~d}, J=6.6 \mathrm{~Hz}, 2 \mathrm{H}), 6.59(\mathrm{t}, J=4.1 \mathrm{~Hz}, 1 \mathrm{H}), 3.80(\mathrm{~s}, 4 \mathrm{H}), 3.71$ (s, 2H), $3.61(\mathrm{dt}, J=18.9,5.6 \mathrm{~Hz}, 4 \mathrm{H}), 2.46(\mathrm{~d}, J=7.9 \mathrm{~Hz}, 2 \mathrm{H}), 1.86-1,78(\mathrm{~m}, 2 \mathrm{H}), 1.67-1,65(\mathrm{~m}$, $2 \mathrm{H}), 1.58-1.49(\mathrm{~m}, 2 \mathrm{H}), 1.38(\mathrm{~m}, 9 \mathrm{H}) .{ }^{13} \mathrm{C}$ NMR (101 MHz, Acetone- $\left.d_{6}\right) \delta 171.3,153.4,149.5$, 143.9, 137.3, 137.0, 128.9, 127.0, 126.6, 124.2, 107.6, 104.7, 50.9, 50.3, 46.3, 45.7, 42.2, 35.4, 33.3, 33.3, 31.5, 27.4, 25.3.. HRMS (ESI) $[\mathrm{M}+\mathrm{H}]^{+}$for $\mathrm{C}_{27} \mathrm{H}_{36} \mathrm{ON} 4 \mathrm{Cl} \mathrm{m} / \mathrm{z}$ Found 467.2566. Calculated 467.2572 IR (Neat) 3197, 2981, 1619, 1479, 1433, 1233, 1019.

\section{1-(4-(2-(4-tert-butylphenyl)-1H-benzo[d]imidazol-4-yl) piperazin-1-yl)-6-iodohexan-1-one (4e)}

$0.077 \mathrm{~g}(0.165 \mathrm{mmol})$ of 1-(4-(2-(4-tert-butylphenyl)-1H-benzo[d]imidazol-4-yl)piperazin-1yl)-6-iodohexan-1-one (2e) was added to a solution containing $3 \mathrm{~mL}$ of acetone and $124 \mathrm{mg}(0.83$ 
mmol, 5 equiv.) NaI. The solution was heated to $55^{\circ} \mathrm{C}$ under reflux and stirred for 16 hours. Then it was filtered to and transferred to a vial for HPLC. Method for HPLC separation; $25 \mathrm{ml} / \mathrm{min}$. initial 95\% $\mathrm{H}_{2} \mathrm{O} 0.1 \%$ TFA, 5\% ACN 0.1\% TFA. At 13 minutes linear change to 5\% $\mathrm{H}_{2} \mathrm{O} 0.1 \%$ TFA, 95\% ACN 0.1\% TFA. Product fractions were collected and lyophilized to provide white powder (10 mg, 11\% yield). Purity 98.22\%. ${ }^{1}$ H NMR (400 MHz, Acetone- $\left.d_{6}\right) \delta 8.32-8.17$ (m, 2H), 7.69 $(\mathrm{d}, J=8.6 \mathrm{~Hz}, 1 \mathrm{H}), 7.45(\mathrm{~d}, J=8.1 \mathrm{~Hz}, 1 \mathrm{H}), 7.36(\mathrm{t}, J=8.0 \mathrm{~Hz}, 1 \mathrm{H}), 6.98(\mathrm{~d}, J=7.9 \mathrm{~Hz}, 1 \mathrm{H}), 3.83$ $(\mathrm{t}, J=5.1 \mathrm{~Hz}, 4 \mathrm{H}), 3.43(\mathrm{t}, J=5.0 \mathrm{~Hz}, 2 \mathrm{H}), 3.37-3.25(\mathrm{~m}, 4 \mathrm{H}), 2.48(\mathrm{t}, J=7.4 \mathrm{~Hz}, 2 \mathrm{H}), 1.89-1,85$ $(\mathrm{m}, 2 \mathrm{H}), 1.74-1.59(\mathrm{~m}, 2 \mathrm{H}), 1.55-1,49(\mathrm{~m}, 2 \mathrm{H}), 1.40(\mathrm{~s}, 9 \mathrm{H}) .{ }^{13} \mathbf{C}$ NMR (101 MHz, Acetone- $\left.d_{6}\right) \delta$ $171.4,156.3,150.2,141.9,135.9,130.3,128.6,127.1,126.4,124.1,112.7,108.3,52.1,51.6,46.1$, 42.0, 35.7, 34.3, 33.2, 31.3, 31.0, 24.9, 7.7.. HRMS (ESI) $[\mathrm{M}+\mathrm{H}]^{+}$for $\mathrm{C}_{27} \mathrm{H}_{36} \mathrm{ON}_{4} \mathrm{I} \mathrm{m} / \mathrm{z}$ Found: 559.1935 Calculated: 559.1928. IR (neat) 2964, 2868, 1629, 1464, 1437, 1197, 1129.

\section{Kinetics experiments}

Compounds 2 (1 equiv.) were added to a solution of acetone-d6 (0.60 mL) and NaI (10 equiv.) in an NMR tube. The reaction were monitored by ${ }^{1} \mathrm{H}-\mathrm{NMR}$, following the disappearance of 2 and appearance of $\mathbf{4}$ by acquisition of a spectrum every 10 minutes over 12 hours unless otherwise specified. For each compound the $\mathrm{CH}_{2}-\mathrm{Cl}$ peak was identified and the rate of the reaction was monitored by the disappearance of the integral. Reaction of 2 a to form 4 a:10 $\mathrm{mg}$ (0.024 mmol, 1 equiv.) of $\mathbf{2 a}$ and $36 \mathrm{mg}$ (0.24 mmol, 10 equiv.) NaI. Reaction of $2 \boldsymbol{b}$ to form $\mathbf{4 b}$ : $10 \mathrm{mg}(0.024$ mmol, 1 equiv.) $2 \mathbf{b}$ and $35 \mathrm{mg}\left(0.24 \mathrm{mmol}, 10\right.$ equiv.) $\mathrm{NaI}$ heated to $60^{\circ} \mathrm{C}$. The reaction was monitored by ${ }^{1} \mathrm{H}-\mathrm{NMR}$ at $1 \mathrm{~h}, 2 \mathrm{~h}, 5 \mathrm{~h}, 8 \mathrm{~h}$ and $11 \mathrm{~h}$. Reaction of 2 c to form $4 \boldsymbol{c}: 10 \mathrm{mg}$ (0.022 mmol, 1 equiv.) $2 \mathrm{c}$ and $33 \mathrm{mg}$ (0.22 mmol, 10 equiv.) NaI, heated to $60^{\circ} \mathrm{C}$. The reaction was monitored by ${ }^{1} \mathrm{H}-\mathrm{NMR}$ at $1 \mathrm{~h}, 2 \mathrm{~h}, 5 \mathrm{~h}, 8 \mathrm{~h}$ and $11 \mathrm{~h}$. Reaction of $2 \boldsymbol{e}$ to form $4 \boldsymbol{e}: 10 \mathrm{mg}$ (0.021 mmol, 1 equiv.) 2e and $32 \mathrm{mg}(0.21 \mathrm{mmol}, 10$ equiv. $) \mathrm{NaI}$ heated to $60^{\circ} \mathrm{C}$. The reaction was monitored by ${ }^{1} \mathrm{H}-\mathrm{NMR}$ at 1h, 2h, 5h, $8 \mathrm{~h}$ and $11 \mathrm{~h}$.

\section{Radiolabeling of 4 a non-carrier added}

$10 \mathrm{~mL}$ of $\mathrm{Na}^{123} \mathrm{I}$ in water $(37 \mathrm{MBq} / \mathrm{mL}$ at $99.9 \%$ purity at calibration time, specific activity $>186 \mathrm{MBq} / \mathrm{nmol}$ ) was obtained from GE Healthcare. Water was removed from $\mathrm{Na}^{123} \mathrm{I}$ by evaporation overnight by a gentle stream of nitrogen gas. Then, $40 \mathrm{mg}(0.1 \mathrm{mmol})$ of $\mathbf{2 a}$ was dissolved in $2 \mathrm{~mL}$ of acetone and added $370 \mathrm{MBq}$ (decay corrected to calibration time) $\mathrm{Na}^{123} \mathrm{I}$ at 
the start of the reaction. The solution was capped in a vial (Biotage microwave reaction glass vial 2-5 $\mathrm{mL}$ ), heated to $60^{\circ} \mathrm{C}$ and stirred for 1 hour. The product was then purified by radio-HPLC with the HPLC method; $10 \mathrm{ml} / \mathrm{min}$. Initial $95 \% \mathrm{H}_{2} \mathrm{O}, 0.1 \%$ TFA, $5 \%$ Acetonitrile (ACN) $0.1 \%$ TFA, then linear change over 3 minutes to $40 \% \mathrm{H}_{2} \mathrm{O} 0.1 \%$ TFA, 60\% ACN 0.1\% TFA, then linear change over 7 minutes to $5 \% \mathrm{H}_{2} \mathrm{O} 0.1 \%$ TFA, 95\% ACN 0.1\% TFA. Each fraction was collected and solvents evaporated, then dissolved in PEG 400:water (4:6). An aliquot was then analyzed by analytical radio-HPLC: $0.5 \mathrm{ml} / \mathrm{min}$. Initial $95 \% \mathrm{H}_{2} \mathrm{O} 0.1 \%$ TFA, $5 \%$ Acetonitrile $0.1 \%$ TFA, then linear change over 20 minutes to $5 \% \mathrm{H}_{2} \mathrm{O} 0.1 \%$ TFA, 95\% ACN $0.1 \%$ TFA.

\section{Microwave reactions}

Reaction of $2 \mathbf{b}$ to $4 \mathbf{b}$ : $10 \mathrm{mg}$ ( $0.024 \mathrm{mmol}, 1$ equiv.) of $7 \mathrm{a}$ was added to a solution of $2 \mathrm{~mL}$ of acetone and $35 \mathrm{mg}\left(0.24 \mathrm{mmol}, 10\right.$ equiv.) of $\mathrm{NaI}$. The solution was heated to $160^{\circ} \mathrm{C}$ in a microwave reactor for 5 minutes, then filtered and analyzed by ${ }^{1} \mathrm{H}-\mathrm{NMR}$. Reaction of $2 \mathbf{d}$ to $4 \mathbf{d}$ : $20 \mathrm{mg}(0.044$ mmol, 1 equiv.) of $6 \mathrm{~d}$ was added to a solution of $2 \mathrm{~mL}$ acetone and $66 \mathrm{mg}$ (0.44 mmol, 10 equiv.) of $\mathrm{NaI}$. The solution was heated to $160^{\circ} \mathrm{C}$ in a microwave reactor for 5 minutes, then filtered and analyzed by ${ }^{1} \mathrm{H}-\mathrm{NMR}$. Reaction of $\mathbf{2 e}$ to $\mathbf{4 e}: 20 \mathrm{mg}(0.043 \mathrm{mmol}, 1$ equiv.) $\mathbf{2 e}$ was added to a solution of $2 \mathrm{~mL}$ acetone and $32 \mathrm{mg}(0.21 \mathrm{mmol}, 5$ equiv. $)$ of NaI. The solution was heated to $160^{\circ} \mathrm{C}$ in a microwave reactor for 5 minutes, then filtered and analyzed by ${ }^{1} \mathrm{H}-\mathrm{NMR}$.

\section{Computational Details}

All the density functional theory (DFT) calculations were performed using the Gaussian 09 program package. ${ }^{[20]}$ The $\omega$ B97XD functional, ${ }^{[21]}$ and 6-311G(d,p) basis sets ${ }^{[22-23]}$ were used for all the calculation of the results used in the main paper. Solvent effects were corrected by using the polarizable continuum model $(\mathrm{PCM})^{[24]}$ in its integral equation formalism (IEFPCM). ${ }^{[25-26]}$ together with acetone as a solvent. For the sake of validating the approach, we performed additional calculations using PBE, ${ }^{[27-28]}$ CAM-B3LYP ${ }^{[29]}$ and M06-L ${ }^{[30]}$ functionals (see the ESI). The optimized geometries were confirmed to be real minima on the potential energy surface with no imaginary frequencies by performing a normal-mode vibrational analysis at the same level of theory. The transition state calculations were confirmed by the presence of an appropriate and a single imaginary vibrational frequency. The Gibbs free energies were calculated at the standard conditions and reported as $\mathrm{kcal} / \mathrm{mol}$. 


\section{RESULTS AND DISCUSSION}

\section{Synthesis of test substrates}

The key bioactive intermediate $\mathbf{1}$ was synthesised according to previously published procedures in $37 \%$ overall yield from 2,6-difluoronitrobenzene (Scheme 2). ${ }^{[19]}$ This template has been shown to effect binding to the $\mathrm{GnRH}$ receptor while maintaining acceptable blood-brain barrier penetration properties. ${ }^{[19]}$ Moreover, our approach relies on the presence of an $\mathrm{N}-\mathrm{H}$ moiety amenable to acylation chemistry which makes compound $\mathbf{1}$ an ideal test substrate.

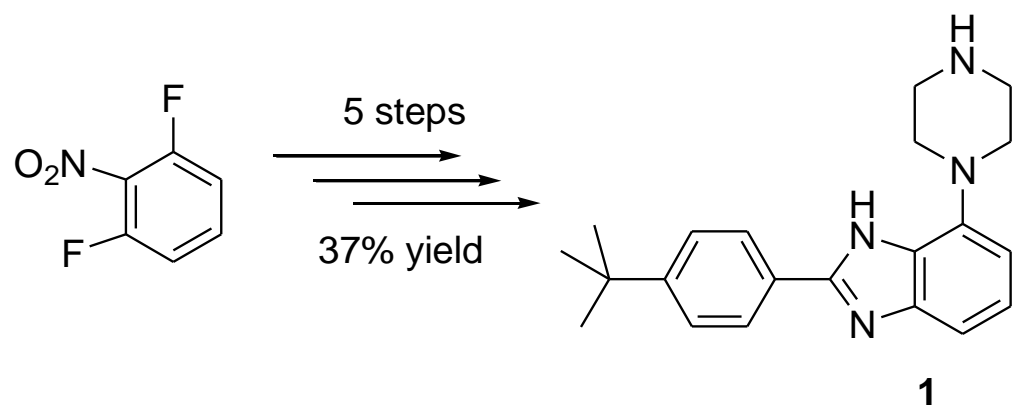

Scheme 2: Synthesis of key intermediate 1. ${ }^{[19]}$

Acylated chlorides 2a-e were generated as shown in Scheme 3. Treatment of $\mathbf{1}$ with chloroacyl chlorides 3a-e in the presence of excess diisopropylethylamine (DIPEA) in DMF afforded products 2a-e in $24-67 \%$ yields (Scheme 3 ).

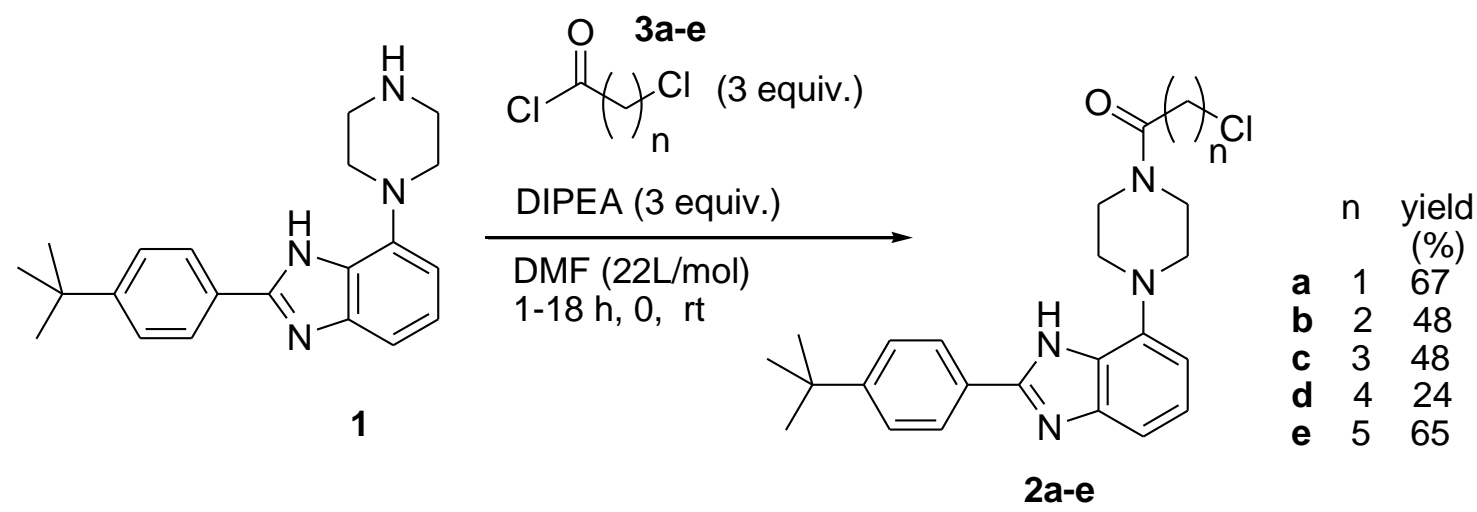

Scheme 3: Acylation of intermediate 1.

The halogen exchange reactions on 2a-e were conducted using excess $\mathrm{NaI}$ in acetone until full conversion of the starting materials were observed (Scheme 4). In general, the isolated chemical 
yields were poor (11-37\%). 2a proceeded readily at ambient temperature in $67 \%$ yield, whereas the other analogues required heating to $55^{\circ} \mathrm{C}$ to achieve reasonable conversion rates. The low chemical yields can also be coupled to incomplete precipitation of sodium chloride, which is a central driving force for the Finkelstein reaction. In an attempt to boost yields and shorten reaction times, we decided to try a microwave-assisted approach for compound $\mathbf{2 d}(n=4)$. Treatment of compound 2d with 10 equivalents of sodium iodide in acetone for 5 minutes at $160^{\circ} \mathrm{C}$ in microwave, afforded the desired product $\mathbf{4 d}$ in $26 \%$ yield. In ${ }^{1} \mathrm{H}-\mathrm{NMR}$ we observed full conversion of all substrates, so the poor isolated yields were likely due to instability issues in the work-up and isolation steps. Interestingly, we were unable to isolate the expected product $\mathbf{4 c}(\mathrm{n}=3)$. The major isolated compound was $\mathbf{5}$ in which the acyl chain was completely gone and an iodide had been substituted on the benzimidazole core. An explanation for these observations will be discussed in the mechanism section.

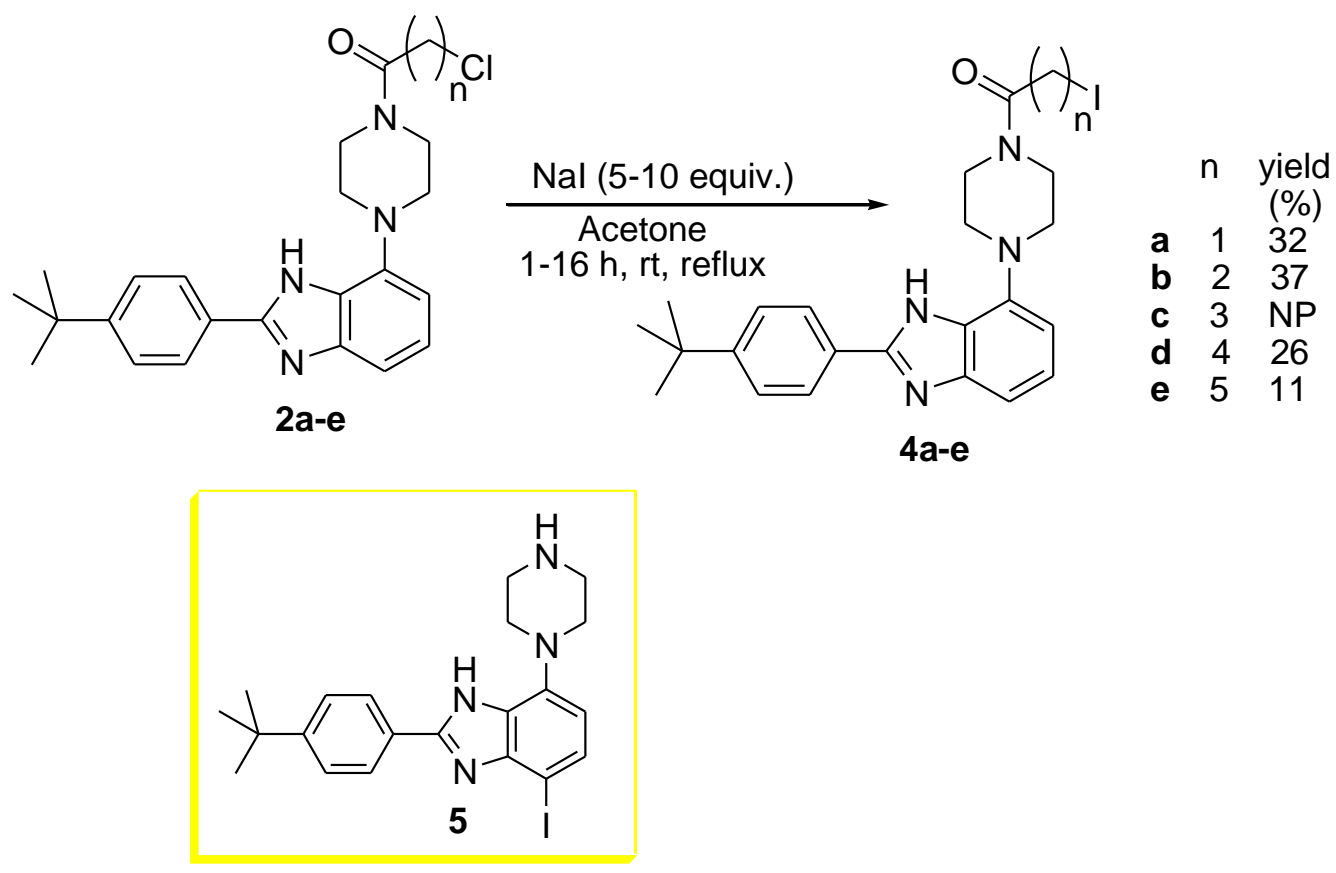

Scheme 4: Finkelstein reactions on chloroamides $\mathbf{2 a - e}$, and the identified compound $\mathbf{5}$ from the reaction of $2 \mathbf{c}$.

\section{Reaction rates}

In order to get a quantitative handle on the relative rates of halide substitution in the various substrates, the reaction progress for the iodination reactions were monitored by ${ }^{1} \mathrm{H}-\mathrm{NMR}$. Semilogarithmic plots of the $\mathrm{CH}_{2}-\mathrm{Cl}$ peak integral versus reaction time would indicate whether the 
reactions display the expected pseudo-first order kinetics. The corresponding $\mathrm{CH}_{2}-\mathrm{I}$ peak signal was also monitored to ensure conversion occurred to the desired product compounds. The iodinations were performed in an NMR tube in deuterated acetone in which a proton NMR spectrum was acquired every 10 minutes. The reaction rate of $\mathbf{2 a}$ was very high and formation of $\mathbf{4 a}$ was complete before 10 minutes had passed. The other reactions were conducted at $60^{\circ} \mathrm{C}$. Compounds 2b, 2d and 2e displayed clear pseudo-first order kinetics and the corresponding observed rate constants (moduli of the slopes) are summarized in Figure 1. The rates are remarkably similar, but the conversion of $2 \mathbf{e}\left(0.061 \mathrm{~h}^{-1}\right)$ appeared to be the most rapid after $\mathbf{2 a}$. The experimentally observed rate constants $\left(k_{o b s}\right)$ for initial disappearance of the starting acyl chloride must be understood in terms of contribution from two mechanistic pathways as shown in Equation 1 and Scheme 5.

$$
k_{\text {obs }}=\left(k_{S N 2}\left[\mathrm{I}^{-}\right]+k_{\text {Anchimeric }}\right)
$$

where $k_{S N 2}$ is the bimolecular rate constant from direct $S_{N} 2$-substitution and $k_{\text {Anchimeric }}$ is the unimolecular rate constant from cyclization of the amide. The similarity of the rates could suggest significant contributions from both terms in the three cases. A detailed computational analysis was conducted to obtain a deeper understanding of the data.

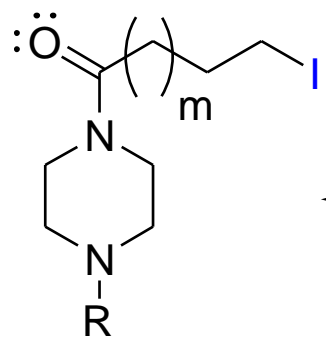

7a-e $(R=H)$

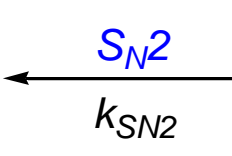

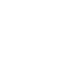




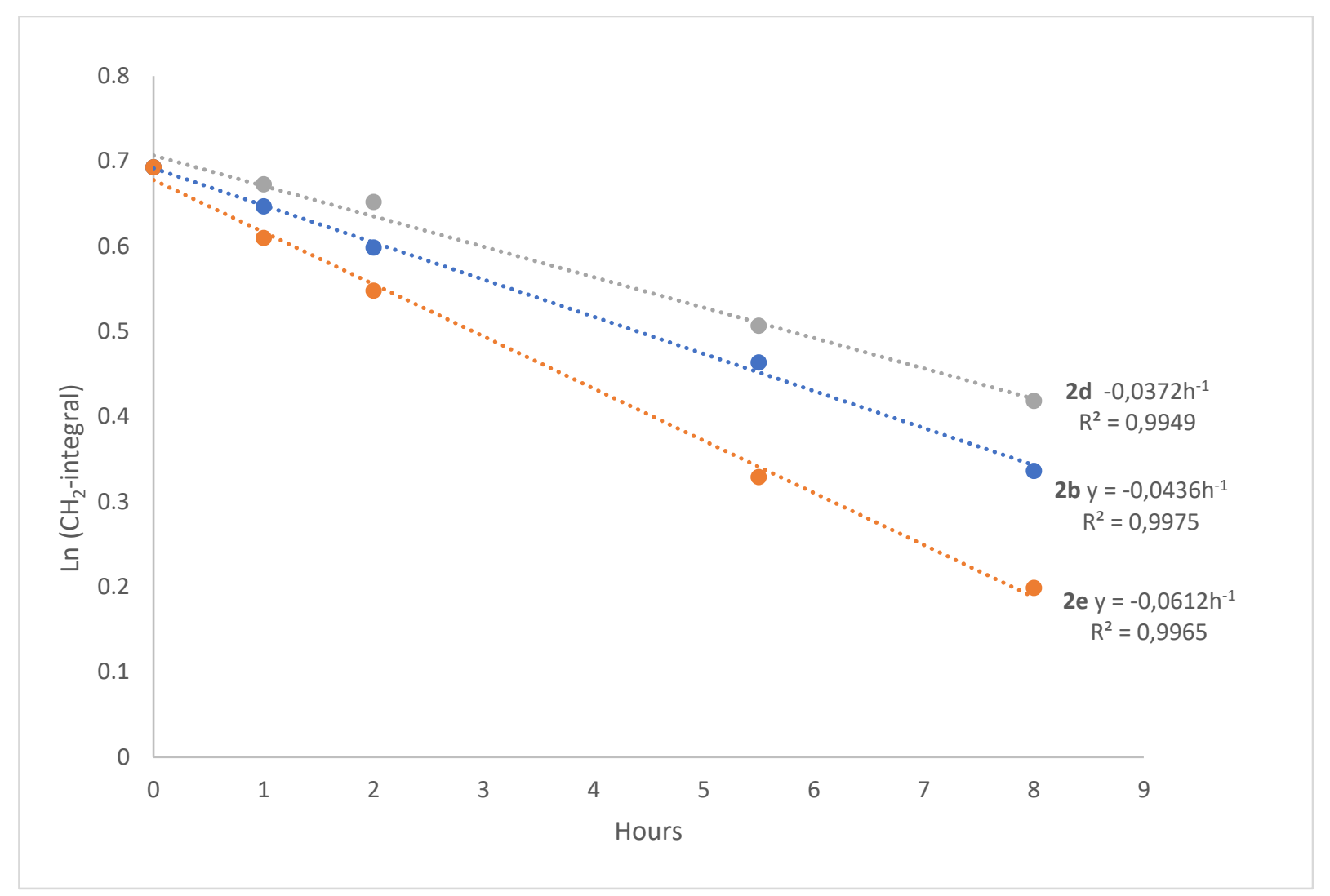

Figure 1: Semi-logarithmic plots for the disappearance of $\mathbf{2 b}, \mathbf{2 d}$ and $\mathbf{2 e}$ with corresponding linear regression analyses.

\section{Mechanistic analysis}

A hypothesis in this work was that the anchimeric effect of the amide group could be employed as a modulating element for the substitution reaction rate. Since amide group anchimeric assistance is sparsely described in the literature, ${ }^{[15,31]}$ and would be of great interest to the physical organic chemistry community, we decided to pursue a deep mechanistic understanding of this phenomenon in our system using density functional theory (DFT) calculations. We have assessed anchimerically assisted pathways in addition to the direct $\mathrm{S}_{\mathrm{N}} 2$ substitution mechanisms for all our model chain lengths using $\omega \mathrm{B} 97 \mathrm{XD} / 6-311 \mathrm{G}(\mathrm{d}, \mathrm{p}) / \mathrm{PCM} /$ Acetone (see the Electronic Supporting Information (ESI) for a discussion about the influence of different DFT methods). In the calculations, we have employed simplified molecules 6a-e (Scheme 5, R = H) as models for 2a-e, where only an acylated piperidine ring has been considered. As the remainder of the molecule is likely to not affect the reactive center to a large extent, this model system was deemed representative. The computed 
barriers were compared with experimental and computed free energies of activation reported for an amide cyclization and Finkelstein reactions by Arcelli et al. ${ }^{[32]}$ and Zaczek et al. ${ }^{[33]}$, respectively. Our computed barriers are in excellent agreement with these reports.

In order to gauge the experimental rates with our computational study and attempt to explain our experimental observations, we computed free energy barriers for direct $\mathrm{S}_{\mathrm{N}} 2$ substitutions on the five model substrates 6a-e based on the potential energy surfaces in Figure 2. Qualitatively, the predicted barriers follow the observed experimental rate trend $\mathbf{6 a}>\mathbf{6 e}>\mathbf{6 d}$. The observed rates for $\mathbf{2 d}$ and $\mathbf{2 b}$ are not very different, so these are hard to distinguish experimentally without more sophisticated experiments. Comparing the faster $\mathbf{2 e}$ with $\mathbf{2 d}$, we see an experimental reaction rate ratio of 1.65 , corresponding to a free energy barrier difference of $0.3 \mathrm{kcal} / \mathrm{mol}$. This is remarkably consistent with the computed free energy barrier difference of $0.4 \mathrm{kcal} / \mathrm{mol}$ for the two $\mathrm{S}_{\mathrm{N}} 2$ reactions, particularly considering error bars for DFT calculations. ${ }^{[34]}$ Since our rate study was conducted with 10-fold excess of iodide to ensure pseudo-first order kinetics, the results likely represent direct $\mathrm{S}_{\mathrm{N}} 2$ substitution reactions of our chloride substrates, which is consistent with the computational study.

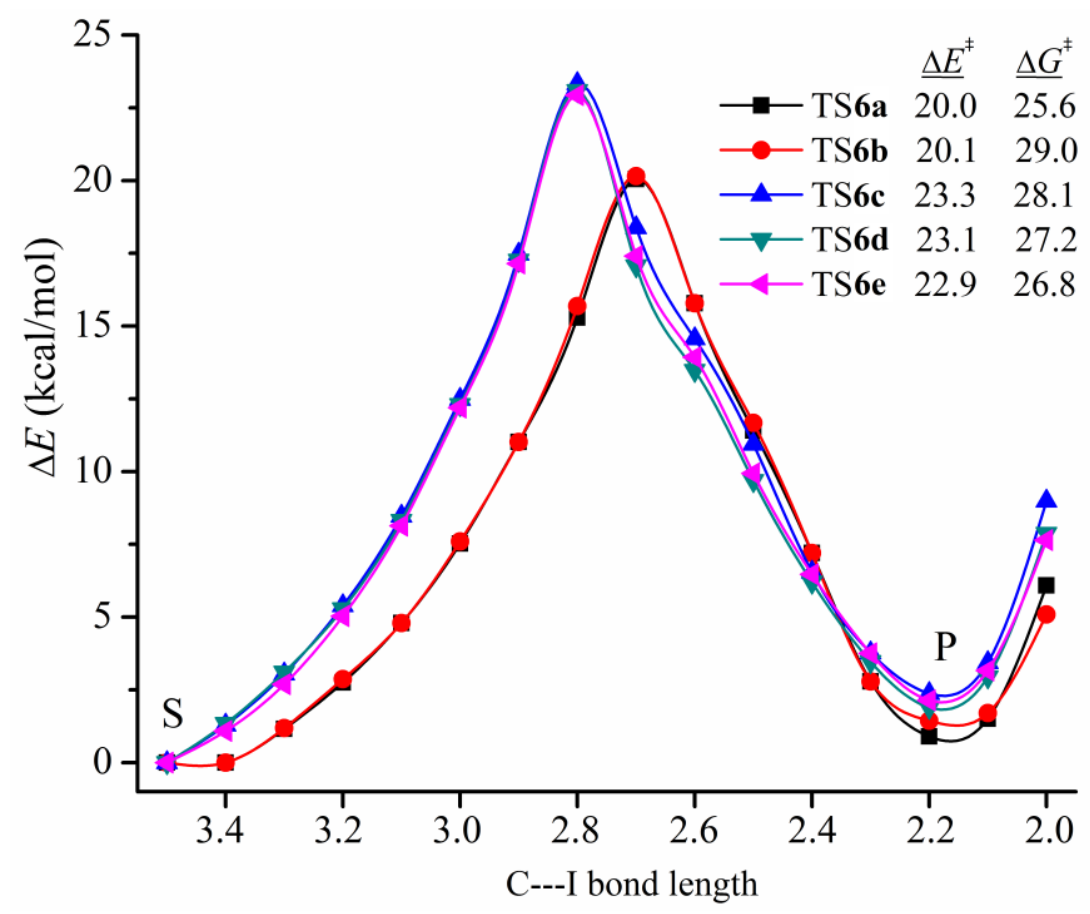

Figure 2. Potential energy surface (PES) for the $\mathrm{S}_{\mathrm{N}} 2$ reactions of 6a-e calculated using $\omega \mathrm{B} 97 \mathrm{XD} / 6-$ $311 \mathrm{G}(\mathrm{d}, \mathrm{p}) / \mathrm{PCM} /$ Acetone. 
Conversion of substrate $6 \mathbf{a}$ to the iodinated product clearly follows a classical $\mathrm{S}_{\mathrm{N}} 2$ pathway owing to the stabilizing interaction the adjacent pi-orbital has on the transition state, and the lack of stability due to ring strain in the hypothetical three-membered intermediate in an anchimerically assisted pathway. This was confirmed by scanning the potential energy surface as shown in Figure 3 , which shows a classical $\mathrm{S}_{\mathrm{N}} 2$ trajectory.

For substrate $\mathbf{6 b}$, the situation becomes more complex (Figure 4). Here the $\mathrm{S}_{\mathrm{N}} 2$ pathway has a $29.0 \mathrm{kcal} / \mathrm{mol}$ barrier versus the alternative anchimerically assisted pathway, in which the amide group expels chloride first, followed by iodide substitution. The latter pathway has a $28.4 \mathrm{kcal} / \mathrm{mol}$ barrier for chloride extrusion, followed by rapid iodide attack on the intermediate product INT6b with a barrier of only $14.8 \mathrm{kcal} / \mathrm{mol}$. Although the anchimerically assisted pathway is slightly faster, there is contribution from the direct $S_{N} 2$ pathway as it has a barrier of only $0.6 \mathrm{kcal} / \mathrm{mol}$ higher than the former. Moreover, at high iodide concentrations, the direct substitution could predominate. The similarity of rate contributions from both mechanisms could explain why $\mathbf{2 b}$ appears to be slightly faster than substrate $\mathbf{2 d}$ in our rate study.

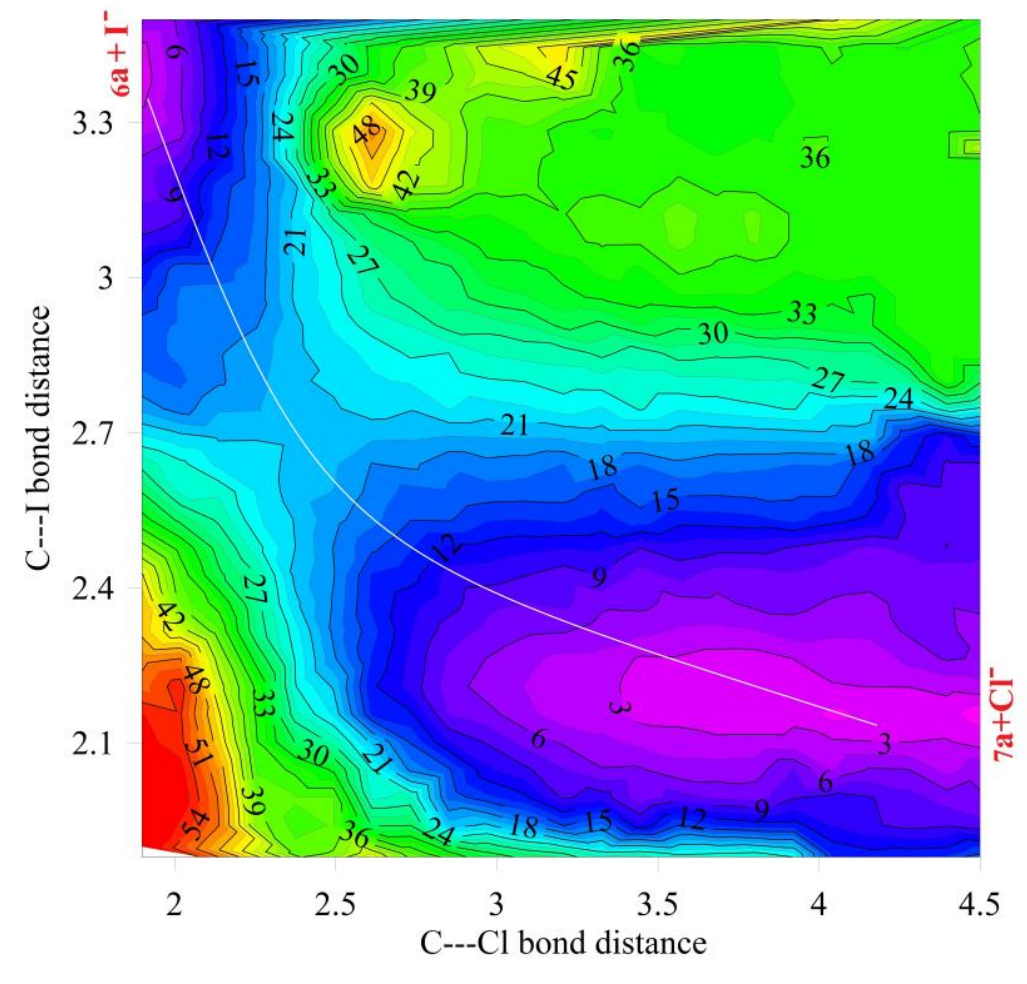


Figure 3. Potential energy surface (PES) for the conversion of $6 \mathbf{a}$ to $7 \mathbf{a}$ calculated using $\omega \mathrm{B} 97 \mathrm{XD} / 6-311 \mathrm{G}(\mathrm{d}, \mathrm{p}) / \mathrm{PCM} /$ Acetone. The conversion of $6 \mathbf{a}$ to $7 \mathbf{a}$ follows an $\mathrm{S}_{\mathrm{N}} 2$ reaction pathway (see the white line).

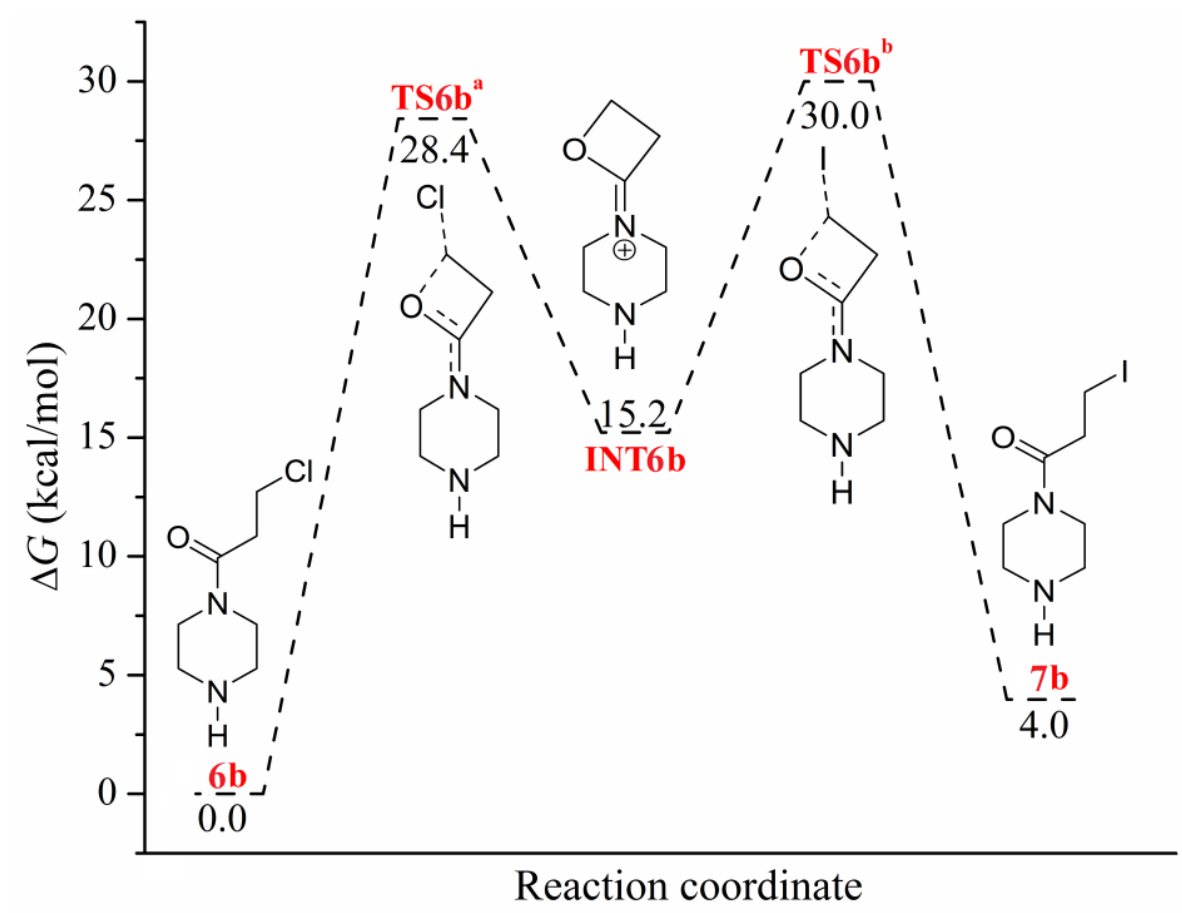

Figure 4. Energy diagram for the anchimerically assisted halogen exchange reaction mechanism in substrate $\mathbf{6 b}$.

Although we did not observe the desired product in case of substrate $\mathbf{2 c}$, we computed free energy surfaces for both anchimerically assisted and direct $\mathrm{S}_{\mathrm{N}} 2$ pathways for the model compound $\mathbf{6 c}$ also (Figure 5). Here the anchimerically assisted pathway is predominant because of the $7.2 \mathrm{kcal} / \mathrm{mol}$ lower free energy barrier. Furthermore, the calculations reveal why this substrate behaves significantly different from the others. In this case, the cyclic intermediate is considerably more stable than the substrate $\mathbf{6 c}$ by $3.6 \mathrm{kcal} / \mathrm{mol}$, making INT6c a predominant reactive species in the solution. The high concentration of INT6c, as well as the relatively high barrier for its iodide substitution $(31.4 \mathrm{kcal} / \mathrm{mol})$, would render it more susceptible to hydrolysis and other side reactions, which would explain the observation of hydrolyzed by-product 5 lacking the acyl group and none of the desired iodinated product. 


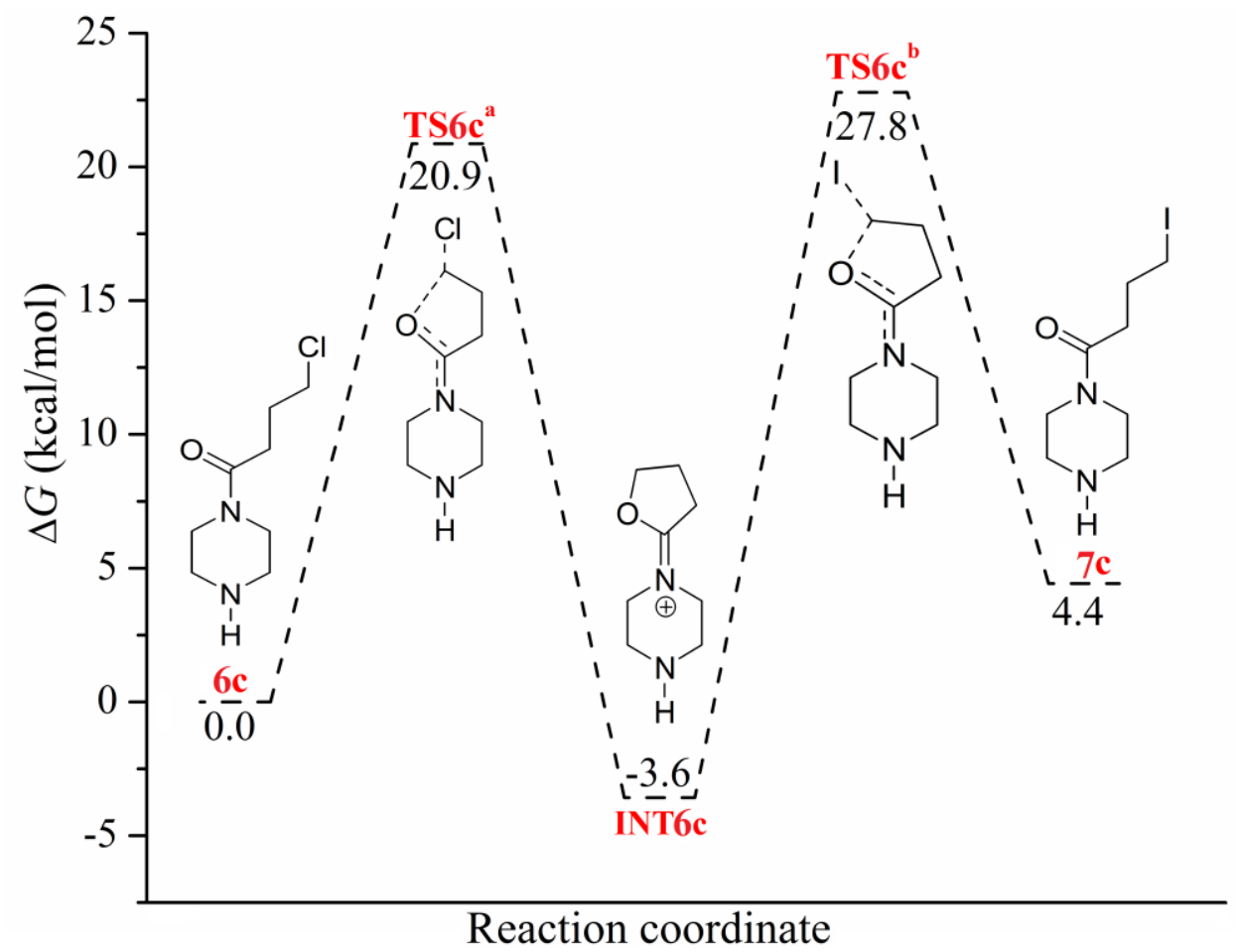

Figure 5. Energy diagram for the halogen exchange reaction mechanism in substrate $\mathbf{6 c}$.

The anchimeric pathway with $\mathbf{6 d}$ is favored as the cyclization barrier is $22.5 \mathrm{kcal} / \mathrm{mol}$, about 5 $\mathrm{kcal} / \mathrm{mol}$ smaller than the direct $\mathrm{S}_{\mathrm{N}} 2$ pathway (Figure 6). The cationic intermediate INT6d is 6.5 $\mathrm{kcal} / \mathrm{mol}$ less stable than the reactants, but can rapidly react with iodide ions to form the corresponding product $7 \mathbf{d}$ with a barrier of only $17.4 \mathrm{kcal} / \mathrm{mol}$. At low iodide concentrations, this is certainly the predominant pathway. Unsurprisingly, the cyclization barrier goes up when moving to the 7-membered ring cyclization of $\mathbf{6 e}$ with a $25.3 \mathrm{kcal} / \mathrm{mol}$ barrier (Figure 7). Otherwise the situation is similar to that of the pathway for $\mathbf{6 d}$.

The Finkelstein reaction depends on coupling with the precipitation of sodium chloride to provide a driving force for the reaction. Our computational study demonstrates the endergonic nature of these reactions in the absence of considering the precipitation process. The precipitation of sodium chloride will render the chloride expulsion step irreversible. 


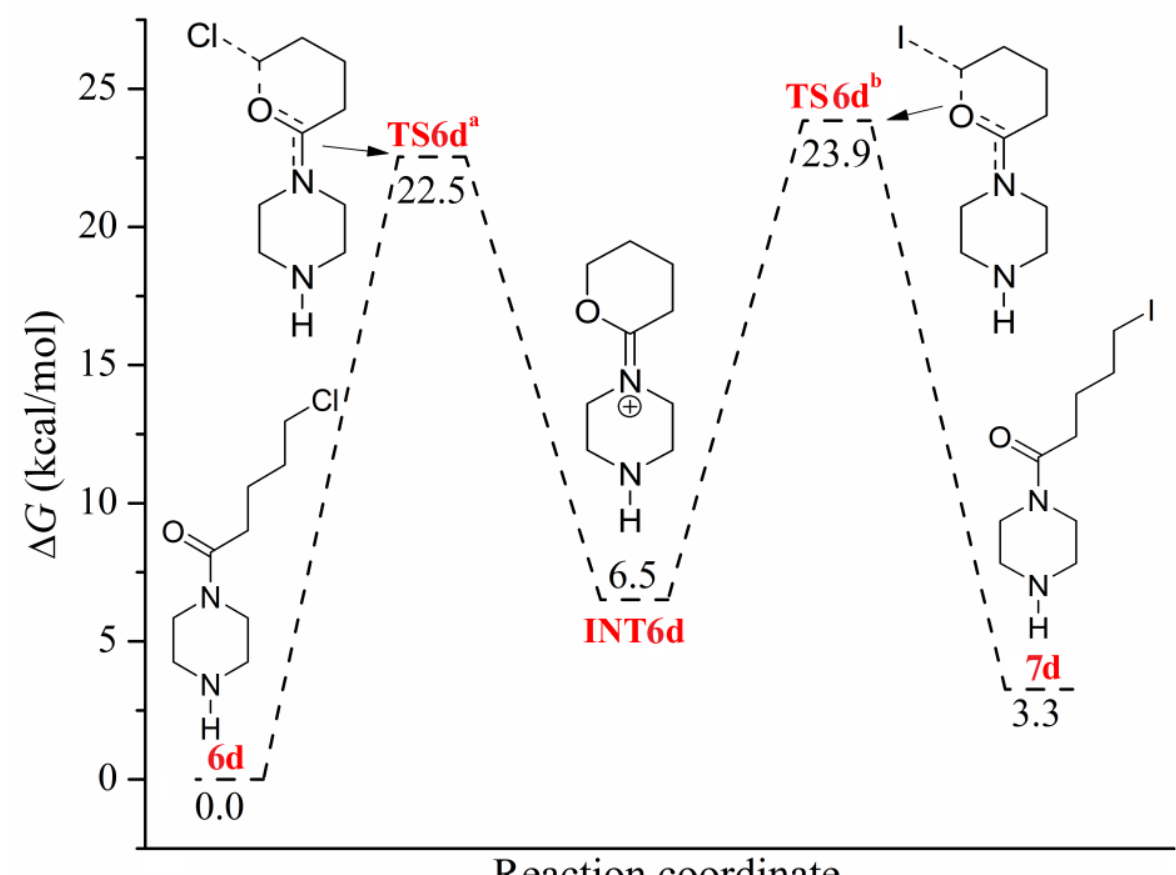

Figure 6. Energy diagram for the halogen exchange reaction mechanism in substrate $\mathbf{6 d}$.

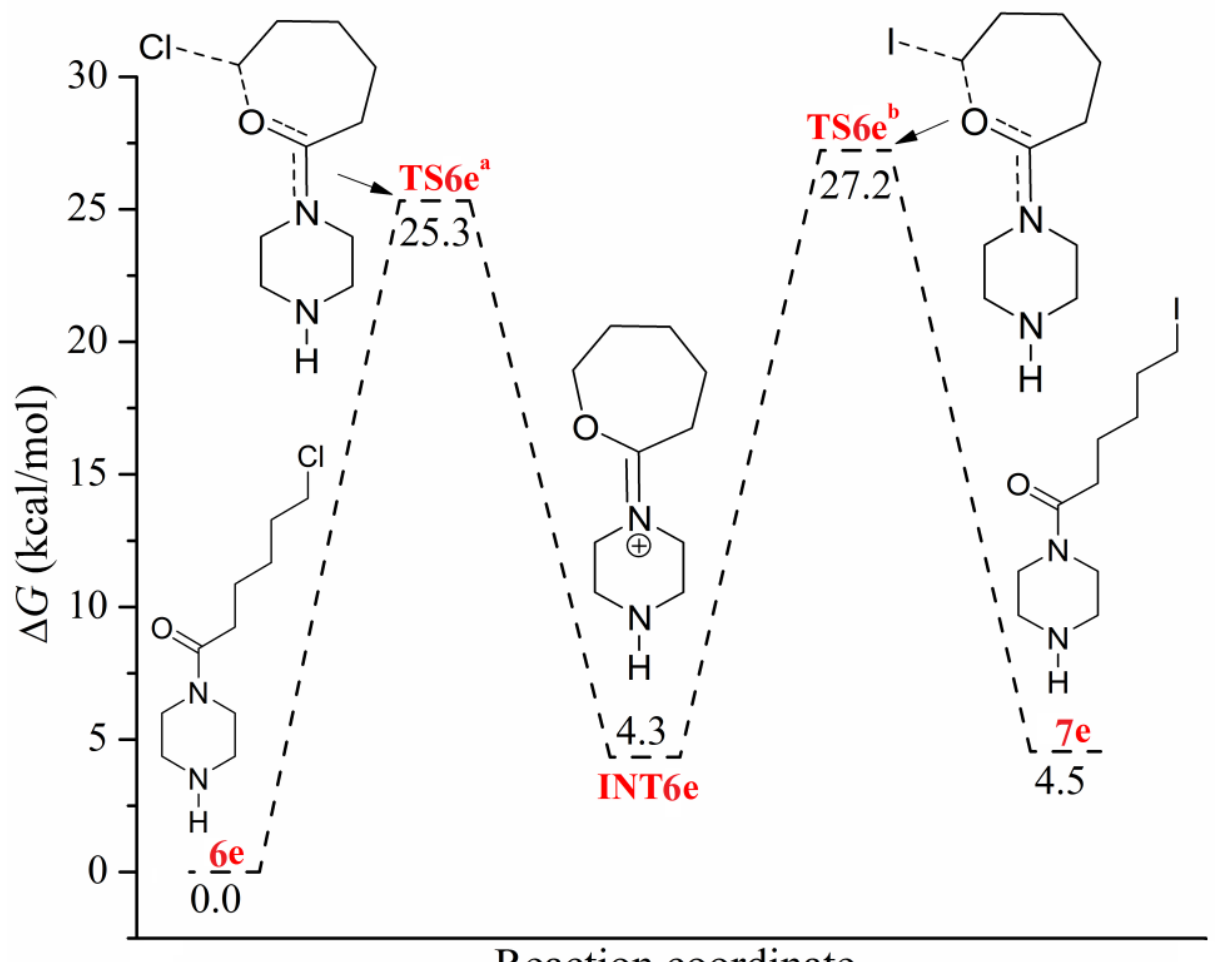

\section{Reaction coordinate}

Figure 7. Energy diagram for the halogen exchange reaction mechanism in substrate $6 \mathbf{e}$. 


\section{Radiolabelling studies}

Although our mechanistic analysis of the reactions above revealed that anchimeric assistance modulation of substitution rates is not straightforward, we decided to attempt radiolabelling of $\mathbf{2 a}$ to demonstrate the validity of the acylation-Finkelstein approach for radioiodination. Compound 2a readily undergoes substitution and was chosen based on the rapid substitution rate compared to the higher chain analogues. In an attempt to maximize the radiochemical yield (RCY), water in the commercially delivered $\mathrm{Na}^{123}$ I solution was evaporated in a concentration step before the reaction. The reaction of 2a was subsequently analyzed by Radio-HPLC after 1 hour reaction time at $60^{\circ} \mathrm{C}$. The radiochromatogram of labelled ${ }^{123}$ I-4a and HPLC-UV trace of cold $\mathbf{4 a}$ are shown in Figure 8. These chromatograms confirm that the radiolabel is effectively incorporated into $\mathbf{4 a}$.

A non-carrier added approach to the radiolabeling was attempted as shown in Scheme 6, and produced radiolabeled compound ${ }^{123} \mathrm{I}-4 \mathbf{a}$. The radiochemical yield (RCY) was determined by comparing the product peak in the HPLC radiochromatogram relative to $\mathrm{Na}^{123} \mathrm{I}$ and other impurities. The RCYs were not corrected for activity lost in the HPLC, however, we did not observe major losses when the column was screened for residual radioactivity. The RCY determined from radio-HPLC was found to be $80 \%$, whereas decay-corrected RCY for isolated ${ }^{123} \mathrm{I}-4 \mathbf{a}$ was found to be $17 \%$.

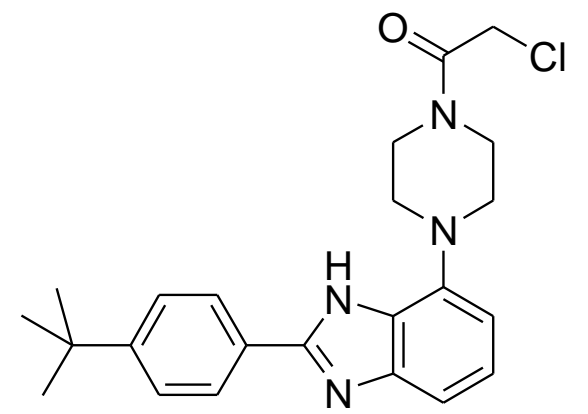

2a

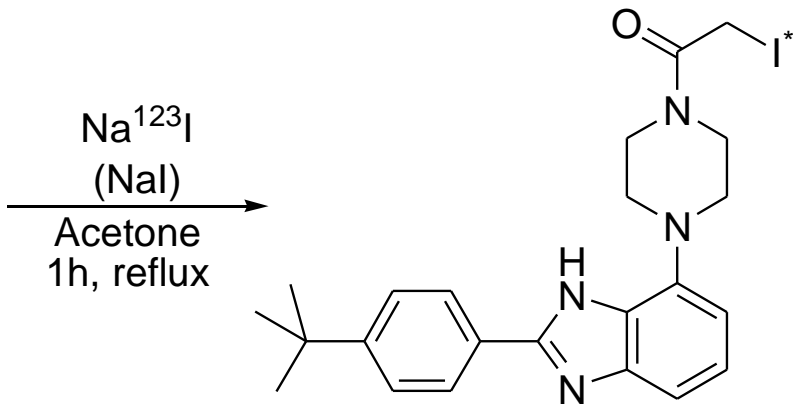

$\mathrm{RCY}$

${ }^{123} \mid-4 a$

Radio-HPLC $80 \%$ Isolated $\quad 17 \%$

Scheme 6: Radiochemical yields (RCYs) observed for ${ }^{123} \mathrm{I}-\mathbf{4 a}$. 


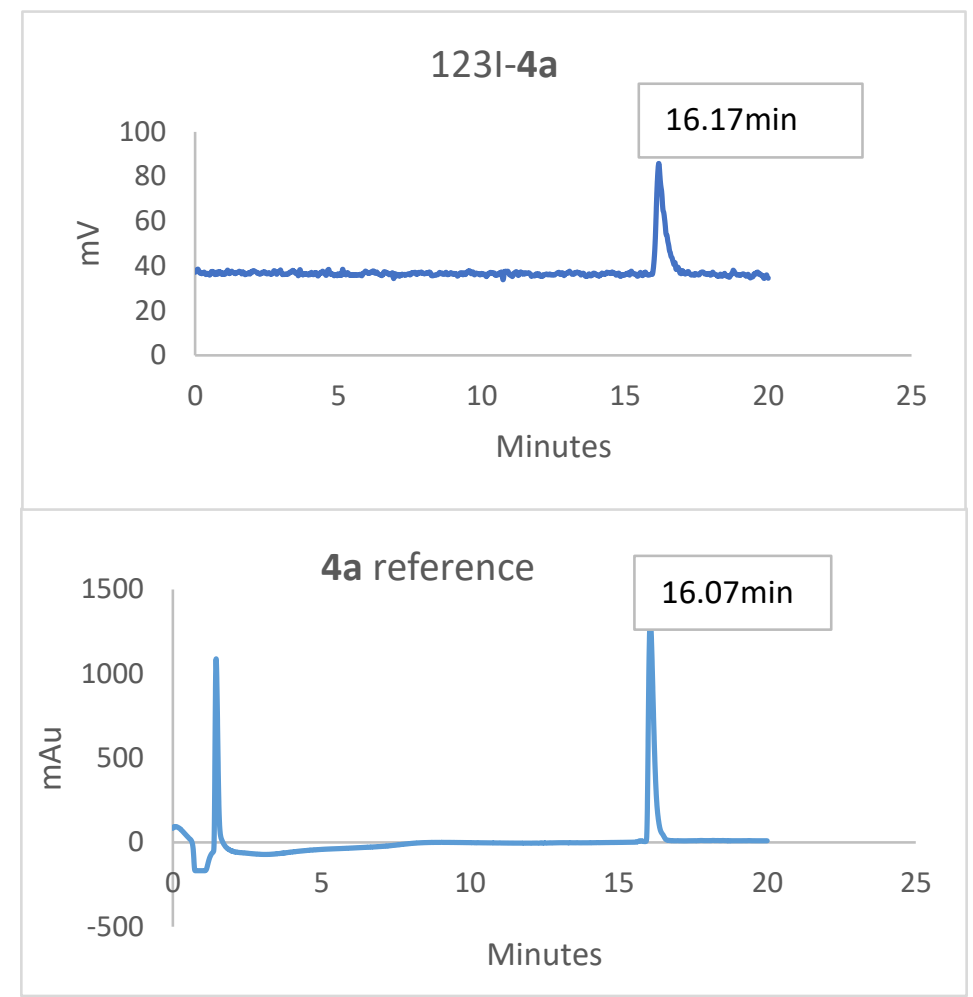

Figure 8: Analytical radiochromatogram of compound ${ }^{123} \mathrm{I}-4 \mathbf{a}$ compared to HPLC-UV (214nm) trace of cold $\mathbf{4 a}$ reference.

Effective radiolabelling reactions must have a reasonable reaction rate in order to be of practical use. In our study, only compound 2a underwent radioiodination at a high rate. However, a weakness with the $\alpha$-iodo substrate is that it is quite reactive and this will cause loss of the radiolabel in physiological settings. As such, the longer chain analogues may be more interesting in order to retain the label longer in the bioactive molecule. However, the substitution rates are rather slow, as is supported by the computed barriers and our kinetic study, even at $60^{\circ} \mathrm{C}$, and the conversions were less than $50 \%$ after $11 \mathrm{hrs}$ reaction time. A possible solution would be to increase the substitution efficiency by employing microwave-irradiation. We tested this hypothesis by conducting the reactions at $160^{\circ} \mathrm{C}$ in a microwave reactor and, to our delight, observed full conversion of all substrates $\mathbf{2 b}, \mathbf{2 d}$ and $\mathbf{2 e}$ to the corresponding iodides by NMR after only 5 minutes of reaction time (see ESI). This approach allows us to employ the different chain lengths as desired and we can expect to achieve radiolabelling in minutes. Moreover, we have shown that the longer chains display relatively slow substitution rates at ambient temperatures, which could render them more 
interesting for imaging applications as they would retain the radiolabel longer in physiological settings.

\section{CONCLUSIONS}

We have demonstrated a straight-forward acylation-Finkelstein approach to iodination and radioiodination of amine-containing bioactives by using a recently developed GnRH antagonist scaffold as a model system. The approach implies the use of anchimeric assistance by amide groups to modulate radiosubstitution rates, which has been studied in molecular detail using chemical synthesis, kinetics, high-level DFT-calculations and radiolabelling studies. The mechanistic studies have revealed a complex interplay between competing mechanistic pathways and solvent effects and show several fundamental aspects of amide group anchimeric assistance that have previously not been reported. Amide group anchimeric assistance only appears to potentially increase substitution reaction rates when 5- and 6-membered ring intermediates are involved. In the 5membered ring intermediate, its stability rendered it susceptible to side reactions.

Despite limitations, we have successfully conducted iodination in several systems and our study shows that this strategy is most promising with the use of 2, 3, 5 and 6-carbon chloroacyl groups. Radioiodination was demonstrated on the C2-system in very high analytical radiochemical yield of $80 \%$. A major conclusion is also that iodination could be effected rapidly under microwave conditions for the slower 3-, 5- and 6-carbon systems, while they remain substitutionally stable at physiological temperature - a potential major advantage for in vivo activity and further studies in this area are underway.

\section{Acknowledgments}

The authors gratefully acknowledge funding for this project from Helse Nord [SFP1196-14 for R.F.] and the Department of Chemistry at UiT The Arctic University of Norway [T.B.D. and J.H.H.]. Computational resources were generously made available from NOTUR [grant no nn4654k for T. B. D.]. Mr. Jostein Johansen and Dr. Johan Isaksson are acknowledged for assistance with mass spectrometry and NMR experiments, respectively.

\section{Supplementary Materials}


Detailed supplementary information, optimized geometries and spectra are available as electronic supplementary information (ESI).

\section{REFERENCES}

[1] G. B. Saha, in Fundamentals of Nuclear Pharmacy, Springer New York, New York, NY, 1992, pp. 80-108.

[2] M. I. Page, W. P. Jencks, Proc. Natl. Acad. Sci. U.S.A. 1971, 68, 1678-1683.

[3] T. C. Bruice, F. C. Lightstone, Acc. Chem. Res. 1999, 32, 127-136.

[4] F. C. Lightstone, T. C. Bruice, J. Am. Chem. Soc. 1996, 118, 2595-2605.

[5] K. N. Houk, J. A. Tucker, A. E. Dorigo, Acc. Chem. Res. 1990, 23, 107-113.

[6] F. M. Menger, Acc. Chem. Res. 1985, 18, 128-134.

[7] T. C. Bruice, U. K. Pandit, J. Am. Chem. Soc. 1960, 82, 5858-5865.

[8] A. J. Kirby, N. H. Williams, J. Chem. Soc., Chem. Commun. 1991, 1643-1644.

[9] (a) T. Cohen, J. Lipowitz, J. Am. Chem. Soc. 1964, 86, 5611-5616. (b) J. Suh, S. S. Yoon, E. Oh, C. Kang, E. Lee, Bioorg. Chem. 1988, 16, 245-257, and references therein.

[10] M. S. Macauley, G. E. Whitworth, A. W. Debowski, D. Chin, D. J. Vocadlo, J. Biol. Chem. 2005, 280, 25313-25322.

[11] N. Çetinbaş, M. S. Macauley, K. A. Stubbs, R. Drapala, D. J. Vocadlo, Biochemistry 2006, 45, 3835-3844.

[12] R. J. Dennis, E. J. Taylor, M. S. Macauley, K. A. Stubbs, J. P. Turkenburg, S. J. Hart, G. N. Black, D. J. Vocadlo, G. J. Davies, Nat. Struct. Mol. Biol. 2006, 13, 365-371.

[13] B. L. Mark, D. J. Vocadlo, S. Knapp, B. L. Triggs-Raine, S. G. Withers, M. N. G. James, J. Biol. Chem. 2001, 276, 10330-10337.

[14] S. Knapp, D. Vocadlo, Z. Gao, B. Kirk, J. Lou, S. G. Withers, J. Am. Chem. Soc. 1996, 118, 6804-6805.

[15] M. Calvaresi, S. Rinaldi, A. Arcelli, M. Garavelli, J. Org. Chem. 2008, 73, 2066-2073.

[16] M. Médoc, F. Sobrio, J. Org. Chem. 2015, 80, 10086-10097.

[17] H. Finkelstein, Ber. Dtsch. Chem. Ges. 1910, 43, 1528-1532.

[18] R. D. Pace, Y. Regmi, J. Chem. Educ. 2006, 83, 1344. 
[19] R. Fjellaksel, M. Boomgaren, R. Sundset, I. H. Haraldsen, J. H. Hansen, P. J. Riss, MedChemComm 2017, 8, 1965-1969.

[20] Gaussian 09, Revision D01, M. J. Frisch, G. W. Trucks, H. B. Schlegel, G. E. Scuseria, M. A. Robb, J. R. Cheeseman, G. Scalmani, V. Barone, B. Mennucci, G. A. Petersson, H. Nakatsuji, M. Caricato, X. Li, H. P. Hratchian, A. F. Izmaylov, J. Bloino, G. Zheng, J. L. Sonnenberg, M. Hada, M. Ehara, K. Toyota, R. Fukuda, J. Hasegawa, M. Ishida, T. Nakajima, Y. Honda, O. Kitao, H. Nakai, T. Vreven, J. Montgomery, J. A., J. E. Peralta, F. Ogliaro, M. Bearpark, J. J. Heyd, E. Brothers, K. N. Kudin, V. N. Staroverov, R. Kobayashi, J. Normand, K. Raghavachari, A. Rendell, J. C. Burant, S. S. Iyengar, J. Tomasi, M. Cossi, N. Rega, J. M. Millam, M. Klene, J. E. Knox, J. B. Cross, V. Bakken, C. Adamo, J. Jaramillo, R. Gomperts, R. E. Stratmann, O. Yazyev, A. J. Austin, R. Cammi, C. Pomelli, J. W. Ochterski, R. L. Martin, K. Morokuma, V. G. Zakrzewski, G. A. Voth, P. Salvador, J. J. Dannenberg, S. Dapprich, A. D. Daniels, O. Farkas, J. B. Foresman, J. V. Ortiz, J. Cioslowski, D. J. Fox, Gaussian, Inc., Wallingford CT, USA, 2009.

[21] J.-D. Chai, M. Head-Gordon, Phys. Chem. Chem. Phys. 2008, 10, 6615-6620.

[22] M. N. Glukhovtsev, A. Pross, M. P. McGrath, L. Radom, J. Chem. Phys. 1995, 103, 18781885.

[23] R. Krishnan, J. S. Binkley, R. Seeger, J. A. Pople, J. Chem. Phys. 1980, 72, 650-654.

[24] J. Tomasi, B. Mennucci, R. Cammi, Chem. Rev. 2005, 105, 2999-3094.

[25] E. Cancès, B. Mennucci, J. Tomasi, J. Chem. Phys. 1997, 107, 3032-3041.

[26] B. Mennucci, J. Tomasi, J. Chem. Phys. 1997, 106, 5151-5158.

[27] J. P. Perdew, K. Burke, M. Ernzerhof, Phys. Rev. Lett. 1997, 78, 1396-1396.

[28] J. P. Perdew, K. Burke, M. Ernzerhof, Phys. Rev. Lett. 1996, 77, 3865-3868.

[29] T. Yanai, D. P. Tew, N. C. Handy, Chem. Phys. Lett. 2004, 393, 51-57.

[30] Y. Zhao, D. G. Truhlar, Theor. Chem. Acc. 2008, 120, 215-241.

[31] A. Guiotto, M. Canevari, M. Pozzobon, S. Moro, P. Orsolini, F. M. Veronese, Bioorg. Med. Chem. 2004, 12, 5031-5037.

[32] A. Arcelli, G. Porzi, S. Rinaldi, S. Sandri, J. Phys. Org. Chem. 2004, 17, 289-293.

[33] S. Zaczek, F. Gelman, A. Dybala-Defratyka, J. Phys. Chem. A. 2017, 121, 2311-2321.

[34] S. E. Wheeler, A. Moran, S. N. Pieniazek, K. N. Houk, J. Phys. Chem. A 2009, 113, 1037610384. 
